\title{
Bioactive Constituents of Juniperus turbinata Guss. from La Maddalena Archipelago
}

\author{
Alessandro Venditti, ${ }^{* a}$ Filippo Maggi, ${ }^{\mathrm{b}}$ Luana Quassinti, ${ }^{\mathrm{b}}$ Massimo Bramucci, ${ }^{\mathrm{b}}$ Giulio Lupidi, ${ }^{\mathrm{b}}$ \\ Luigi Ornano, ${ }^{a}$ Mauro Ballero, ${ }^{c}$ Cinzia Sanna, ${ }^{d}$ Maurizio Bruno, ${ }^{e}$ Sergio Rosselli, ${ }^{e}$ and \\ Armandodoriano Bianco ${ }^{a}$ \\ aDipartimento di Chimica, Università di Roma "La Sapienza", Piazzale Aldo Moro 5, 00185 Rome, Italy, e-mails: \\ alessandro.venditti@gmail.com; alessandro.venditti@uniroma1.it

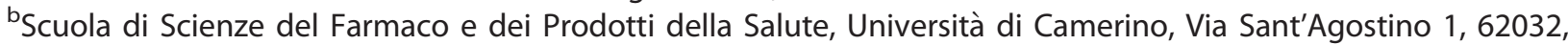 \\ Camerino, Italy \\ ${ }^{\circ} \mathrm{CoSMeSe}$, Consorzio per lo Studio dei Metaboliti Secondari, Via Sant'Ignazio 13, 09123, Cagliari, Italy \\ ${ }^{d}$ Dipartimento di Scienze della Vita e dell'Ambiente, Università di Cagliari, Via Sant'Ignazio 13, 09123, Cagliari, Italy \\ ${ }^{\mathrm{e}}$ Dipartimento di Scienze e Tecnologie Biologiche Chimiche e Farmaceutiche, Università di Palermo, Viale delle \\ Scienze - Parco d'Orleans II Ed. 17, 90128 Palermo, Italy
}

A comprehensive phytochemical study of Juniperus turbinata (Cupressaceae) collected from La Maddalena Archipelago (Sardinia, Italy) is reported. Both the essential oil and the ethanolic extract obtained from the aerial parts were analyzed. The essential oil appears to belong to a new chemotype compared to other Mediterranean juniper accessions, as it was favored by geographic isolation of the isles. It showed a low content of monoterpene hydrocarbons and $\alpha$-terpineol, entmanoyl oxide, 1,10-di-epi-cubenol as the major constituents. The ethanolic fraction contained mainly diterpenoids. Among these, 15-formyloxyimbricatolic acid (7) is a new natural product since it has hitherto been obtained only by synthetic route. The phenolic fraction contained biflavonoids: cupressuflavone (9), followed by minor amounts of amentoflavone (10) and hinokiflavone (11). The essential oil and six purified compounds (1-4, 8 and 9) were assessed for biological activities, namely antioxidant (assessed by DPPH, ABTS ${ }^{+}$and FRAP methods) and cytotoxic effects towards selected human tumor cell lines (MDA-MB 231, A375 and HCT116 cells). Compound $\mathbf{3}$ exhibited higher radical scavenging activity against $\mathrm{ABTS}^{+}$radical than the reference Trolox. Noteworthy, compound $\mathbf{8}$ showed powerful effects towards tumor cell lines, with $\mathrm{IC}_{50}$ values in the range of $0.060-0.201 \mu \mathrm{m}$, which make it a promising anticancer drug candidate.

Keywords: Juniperus turbinata, polar compounds, imbricataloic acid, essential oil, biological activity.

\section{Introduction}

Juniperus turbinata Guss. is a Mediterranean shrub or small tree, up to $6-8 \mathrm{~m}$ tall, belonging to Cupressaceae family. It has been regarded as Juniperus phoenicea ssp. turbinata (Guss.) NYMAN ${ }^{[1][2]}$ or Juniperus phoenicea var. turbinata (Guss.) PARL., ${ }^{[3][4]}$ and included in the Juniperus phoenicea L. complex, along with Juniperus phoenicea s.s. However, according to morphological ${ }^{[5][6]}$ and genetic differences ${ }^{[7]}$ between the two taxa, Juniperus turbinata has recently been accepted at species rank.

J. turbinata grows in coastal areas around the Mediterranean Sea and in the mountains of northwest of Africa, up to $800 \mathrm{~m}$ a.s.l., ${ }^{[8]}$ while J. phoenicea s.s. is present on mountains of Iberian Peninsula, southern France and north-western Italy. ${ }^{[5]}$

The J. phoenicea complex enjoys good reputation as an important medicinal plant as it has largely been used in traditional medicine to heal various illnesses such as dysentery, rheumatism, intestinal, urinary and respiratory problems, ${ }^{[9]}$ diabetes $^{[10][11]}$ and infectious diseases. $^{[12-14]}$

Two major classes of secondary metabolites are found in the Juniperus genus such as terpenoids, with diterpenes as the main compounds, and phenolics, in particular biflavonoids. ${ }^{[15-19]}$

Concerning J. phoenicea, a significant degree of morphological and genetic variability has been reported in literature. ${ }^{[20-24]}$ This may undoubtedly affects the secondary metabolism expression of the species. It is worth of note that most of studies on J. phoenicea are related to its monoterpene-rich essential oil ${ }^{[14][25-29]}$ and the monoterpene hydrocarbon $\alpha$-pinene emerged as the principal characterizing volatile compound. Conversely, the non-volatile secondary metabolites were investigated to a minor extent, and 
the following classes of natural products were the main groups of secondary metabolites characterizing the species J. phoenicea: abietane diterpenoids, ${ }^{[19][30]}$ sesquiterpenes, ${ }^{[31]}$ norterpenoid glucosides, ${ }^{[32]}$ scutellarein derivatives, ${ }^{[33]}$ furanones, phenylpropane glucosides $^{[17][34][35]}$ and lignans. ${ }^{[36]}$ However, in this context, J. turbinata has hitherto been poorly explored and showed labdane diterpenes as the main constituents. $^{[37]}$

The aim of this study was to perform a complete phytochemical analysis on both polar and volatile compounds of $J$. turbinata collected from a geographically isolated population living in the La Maddalena Archipelago and to assess their biological activity, namely the cytotoxicity on a panel of human tumor cells (MDA-MB 231, A375 and HCT116 cells) together with the radical scavenging and ferric reducing antioxidant capacity. For this purpose, the main secondary metabolites occurring in the J. turbinata ethanolic extract were isolated by column chromatography and structurally elucidated by MS and NMR techniques. The essential oil was hydrodistilled from the aerial parts and analyzed by GC-FID and GC/MS. Antioxidant activity and cytotoxic effects of essential oil and six isolated compounds were evaluated by DPPH ${ }^{\circ}, \mathrm{ABTS}^{\circ}$, FRAP and MTT methods, respectively.

\section{Results and Discussion}

\section{Analysis of the Ethanolic Extract}

As already recognized from other Mediterranean populations of J. turbinata, the sample collected from La Maddalena Island showed a huge presence of diterpenoids, which were the major phytochemicals. Among these, imbricatolic acid (1), 13-epi-cupressic acid (2), ent-manoyl oxide (3), $7 \alpha$-hydroxysandaracopimaric acid (4), 13-epi-torulosal (5), sandaracopimaric acid (6), 15-formyloxyimbricatolic acid (7) and imbricataloic acid (8) were identified (Figure 1). In this context, it is worthy to note that the isolation of 15-formyloxyimbricatolic acid (7), from a natural source, is reported here for the first time. In fact, compound (7) was previously obtained by a semisynthesis approach starting from imbricatolic acid (1). ${ }^{[38]}$ From the chemical standpoint, compound 7 may be considered as the oxidation product of 15 -formyloxyimbricatolal, recognized as one of the components of a Chilean resin sample obtained from Araucaria araucana. ${ }^{[39]}$ The identification of compound 7 was performed by applying an extensive bidimensional NMR analysis (using both mono- and bidimensional experiments) and following a method reported in our recent works ${ }^{[40-42]}$ which permit to identify the components of simple mixtures by unequivocal assignment of each resonance signal. In the present case, the assignment of resonances to the respective compounds was simplified because the components were already described in literature, while these methods have previously been applied in the structure elucidation of new natural products. As a new natural compound, the presence of $\mathbf{7}$ is also of high chemosystematic relevance because it was not previously recognized in this species. It might likely be a characteristic phytochemical trait owned by the population living in La Maddalena Island and probably derived by its geographic isolation. We already observed peculiar phytochemical

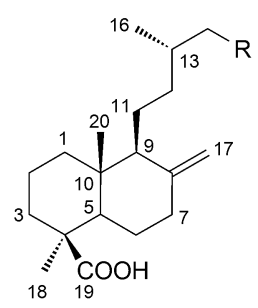

Imbricatolic acid (1) $\mathrm{R}=\mathrm{CH}_{2} \mathrm{OH}$ Imbricataloic acid (8) $\mathrm{R}=\mathrm{CHO}$

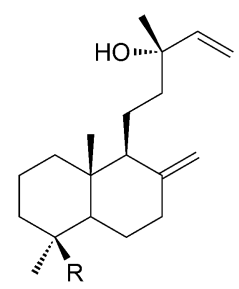

13-epi-Cupressic acid (2) $\mathrm{R}=\mathrm{COOH}$ 13-epi-Torulosal (5) $\mathrm{R}=\mathrm{CHO}$

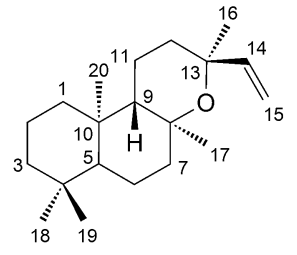

ent-Manoyl oxide (3)

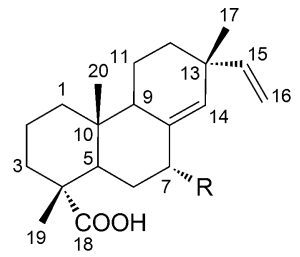

$7 \alpha$-Hydroxysandaracopimaric acid (4) $\mathrm{R}=\mathrm{OH}$ Sandaracopimaric acid (6) $\mathrm{R}=\mathrm{H}$

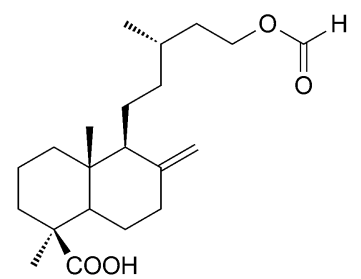

15-Formyloxyimbricatolic acid (7)

Figure 1. Diterpenoids isolated from Juniperus turbinata from La Maddalena Archipelago. 
patterns in the polar fraction obtained from species living in isolated environments, restricted areas or by endemic entities, especially in species collected from Sardinia and La Maddalena islands, ${ }^{[43-51]}$ therefore the results achieved in the present study are a further confirmation of these observations. Moreover, the majority of the diterpenes identified in this study have never been reported as constituents of J. turbinata, and this represent an additional evidence of the influence exerted by the isolated environment on the phytochemical pattern. Making a comparison, the observed diterpene composition was very similar to those observed in J. rigida from Korea ${ }^{[52]}$ and partially to those reported for J. phoenicea s.s. from Saudi Arabia. ${ }^{[53]}$

The minor components of the ethanolic extract belong to the class of flavonoid and resulted to be three bi-apigenin derivatives with apigenin residues coupled in different ways: with the $\mathrm{C}-\mathrm{C}$ linkage in cupressuflavone $\left(\mathbf{9} ; C(8)-C\left(8^{\prime \prime}\right)\right)$ and amentoflavone $\left(10\right.$; $\left.C\left(3^{\prime}\right)-C\left(8^{\prime \prime}\right)\right)$, respectively, and with the $C-O$ linkage in hinokiflavone $\left(\mathbf{1 1} ; \mathrm{C}\left(4^{\prime}\right)-\mathrm{O}-\mathrm{C}\left(6^{\prime \prime}\right)\right.$; Figure 2).

All these biflavonoids were already recognized in Juniperus spp. as well as in the related species of the Cupressaceae family, ${ }^{[18][53][54]}$ while simple flavonoids, reported as constituents in accessions belonging to other populations of J. turbinata, ${ }^{[55][56]}$ were not recognized in the present study.

\section{Composition of the Essential Oil}

The composition of the essential oil of J. turbinata is reported in Table 1. A total of 99 volatile components were identified, corresponding to $91.0 \%$ of the total composition. The major compounds were represented by $\alpha$-terpineol (11.0\%), ent-manoyl oxide $(5.5 \%)$ and 1,10 -di-epi-cubenol (5.1\%). $\alpha$-Terpineol is a safe compound because of its frequent use in fragrances and is being used as a scaffold for the synthesis of new drugs for the treatment of cancer, severe pains and inflammatory disorders. ${ }^{[57][58]}$ The most abundant fraction in the oil was that of oxygenated monoterpenes $(30.8 \%)$, followed by similar levels of sesquiterpene hydrocarbons (23.6\%) and oxygenated sesquiterpenes $(21.7 \%)$. Noteworthy was the presence of diterpenes (10.9\%, ten identified compounds), mainly labdanes, abietanes and pimaranes, among which ent-manoyl oxide was the most abundant. Finally, scarce was the contribution of the monoterpene hydrocarbons with $1.3 \%$ of the total. Other components occurring in significant amounts $(>2 \%)$ in the oil were: trans-verbenol (2.4\%) and piperitone (4.2\%) among oxygenated monoterpenes; $\delta$-cadinene $(3.9 \%), \quad$ germacrene D (2.6\%), epi-bicyclosesquiphellandrene (2.4\%), germacrene B (2.2\%) and $\gamma$-cadinene (2.8\%) for sesquiterpene hydrocarbons; elemol (2.3\%) and shyobunol (3.4\%) for oxygenated sesquiterpenes, and transtotarol (2.1\%) for diterpenes.

Some differences in volatiles were found with respect to other populations of J. turbinata studied previously. Rezzi and collaborators ${ }^{[59]}$ analyzed a population growing in Corsica and found $\alpha$-pinene, $\beta$-phellandrene, $\alpha$-terpinyl acetate, $\delta$-3-carene, myrcene and $\alpha$-phellandrene as the main constituents. Similar composition was observed in populations of J. phoenicea var. turbinata (the previously accepted

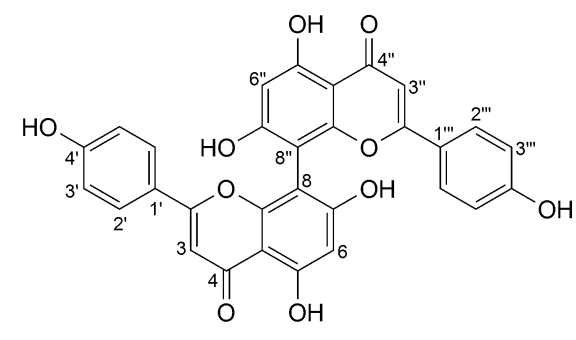

Cupressuflavone (9)

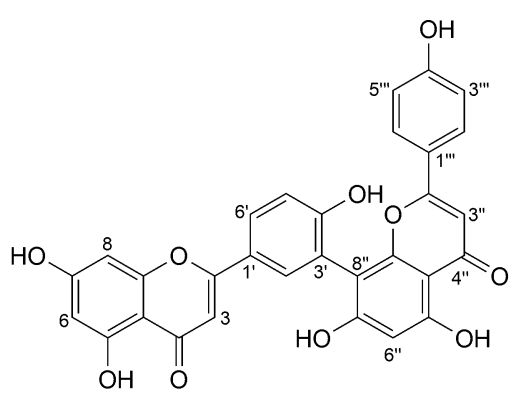

Amentoflavone (10)<smiles>O=c1cc(-c2ccc(Oc3c(O)cc4oc(-c5ccc(O)cc5)cc(=O)c4c3O)cc2)oc2cc(O)cc(O)c12</smiles>

Hinokiflavone (11)

Figure 2. Biflavonoids isolated from Juniperus turbinata from La Maddalena Archipelago. 
Table 1. Essential oil composition of Juniperus turbinata

\begin{tabular}{|c|c|c|c|c|c|c|}
\hline No. & Component $^{[\mathrm{a}]}$ & $\mathrm{RI}^{[\mathrm{b}]}$ & \multicolumn{2}{|l|}{ RI lit. ${ }^{[c]}$} & {$[\%]^{[\mathrm{d}]}$} & $\mathrm{ID}^{[\mathrm{e}]}$ \\
\hline 2 & Myrcene & 991 & 990 & 992 & 0.0 & Std \\
\hline 3 & $\alpha$-Phellandrene & 1003 & 1002 & 1002 & 0.1 & Std \\
\hline 4 & p-Cymene & 1026 & 1024 & 1025 & 0.0 & Std \\
\hline 7 & cis-p-Menth-2-en-1-ol & 1120 & 1121 & 1121 & 0.7 & $\mathrm{RI}, \mathrm{MS}$ \\
\hline 8 & $\alpha$-Campholenal & 1125 & 1126 & 1123 & 0.7 & $\mathrm{RI}, \mathrm{MS}$ \\
\hline 9 & trans-Pinocarveol & 1136 & 1139 & 1137 & 1.3 & Std \\
\hline 10 & trans-p-Menth-2-en-1-ol & 1140 & 1140 & 1140 & 0.4 & $\mathrm{RI}, \mathrm{MS}$ \\
\hline 11 & Camphor & 1141 & 1146 & 1139 & 0.6 & Std \\
\hline 16 & p-Mentha-1,5-dien-8-ol & 1168 & 1170 & 1168 & 0.8 & $\mathrm{RI}, \mathrm{MS}$ \\
\hline 17 & cis-Pinocamphone & 1171 & 1175 & 1170 & 0.3 & $\mathrm{RI}, \mathrm{MS}$ \\
\hline 18 & Terpinen-4-ol & 1176 & 1177 & 1175 & 0.4 & Std \\
\hline 19 & Cryptone & 1183 & 1184 & 1184 & 1.3 & $\mathrm{RI}, \mathrm{MS}$ \\
\hline 20 & $p$-Cymen-8-ol & 1186 & 1182 & 1186 & 0.5 & $\mathrm{RI}, \mathrm{MS}$ \\
\hline 21 & $\alpha$-Terpineol & 1189 & 1188 & 1189 & 11.0 & Std \\
\hline 22 & Myrtenal & 1193 & 1195 & 1193 & 0.4 & $\mathrm{RI}, \mathrm{MS}$ \\
\hline 23 & Myrtenol & 1193 & 1195 & 1193 & 0.6 & Std \\
\hline 24 & Verbenone & 1204 & 1205 & 1204 & 1.1 & Std \\
\hline 25 & trans-Piperitol & 1204 & 1208 & 1205 & 0.6 & $\mathrm{RI}, \mathrm{MS}$ \\
\hline 26 & trans-Carveol & 1218 & 1216 & 1219 & 0.7 & $\mathrm{RI}, \mathrm{MS}$ \\
\hline 34 & p-Cymen-7-ol & 1290 & 1290 & 1289 & 0.1 & $\mathrm{RI}, \mathrm{MS}$ \\
\hline 35 & $\delta$-Elemene & 1334 & 1338 & 1337 & 0.3 & $\mathrm{RI}, \mathrm{MS}$ \\
\hline 36 & $\delta$-Cubebene & 1346 & 1348 & & 0.1 & $\mathrm{RI}, \mathrm{MS}$ \\
\hline 37 & $\delta$-Copaene & 1370 & 1376 & & 0.1 & $\mathrm{RI}, \mathrm{MS}$ \\
\hline 38 & $\beta$-Bourbonene & 1377 & 1388 & 1377 & 0.1 & $\mathrm{RI}, \mathrm{MS}$ \\
\hline 39 & $\beta$-Cubebene & 1385 & 1388 & 1386 & 0.1 & $\mathrm{RI}, \mathrm{MS}$ \\
\hline 40 & $\beta$-Elemene & 1387 & 1390 & 1387 & 0.4 & $\mathrm{RI}, \mathrm{MS}$ \\
\hline 41 & (E)-Caryophyllene & 1409 & 1419 & 1409 & 1.0 & Std \\
\hline 42 & cis-Thujopsene & 1420 & 1431 & & 0.3 & $\mathrm{RI}, \mathrm{MS}$ \\
\hline 43 & 2,5-Dimethoxy- $p$-cymene & 1425 & 1426 & & 0.6 & $\mathrm{RI}, \mathrm{MS}$ \\
\hline 44 & $\gamma$-Elemene & 1429 & 1436 & & 0.8 & $\mathrm{RI}, \mathrm{MS}$ \\
\hline 45 & cis-Muurola-3,5-diene & 1443 & 1450 & & 0.7 & $\mathrm{RI}, \mathrm{MS}$ \\
\hline 46 & $\alpha$-Humulene & 1445 & 1454 & 1446 & 1.1 & Std \\
\hline 47 & trans-Cadina-1(6),4-diene & 1468 & 1476 & & 1.3 & $\mathrm{RI}, \mathrm{MS}$ \\
\hline 48 & Germacrene D & 1473 & 1485 & 1472 & 2.6 & $\mathrm{RI}, \mathrm{MS}$ \\
\hline 49 & $\beta$-Selinene & 1477 & 1490 & 1478 & 0.2 & $\mathrm{RI}, \mathrm{MS}$ \\
\hline 50 & epi-Bicyclosesquiphellandrene & 1482 & & 1471 & 2.4 & $\mathrm{RI}, \mathrm{MS}$ \\
\hline 51 & Valencene & 1485 & 1496 & 1485 & 0.3 & $\mathrm{RI}, \mathrm{MS}$ \\
\hline 52 & epi-Cubebol & 1487 & 1494 & & 1.6 & $\mathrm{RI}, \mathrm{MS}$ \\
\hline 53 & Butylated hydroxyanisole & 1487 & 1489 & & 0.8 & $\mathrm{RI}, \mathrm{MS}$ \\
\hline 54 & $\alpha$-Muurolene & 1494 & 1500 & & 1.0 & $\mathrm{RI}, \mathrm{MS}$ \\
\hline 55 & $\gamma$-Cadinene & 1508 & 1513 & 1509 & 2.8 & $\mathrm{Rl}, \mathrm{MS}$ \\
\hline 56 & trans-Calamenene & 1518 & 1522 & 1517 & 1.0 & $\mathrm{RI}, \mathrm{MS}$ \\
\hline
\end{tabular}


Table 1. (cont.)

\begin{tabular}{|c|c|c|c|c|c|c|}
\hline \multirow[t]{2}{*}{ No. } & \multirow[t]{2}{*}{ Component $^{[\mathrm{a}]}$} & \multirow[t]{2}{*}{$\mathrm{RI}^{[\mathrm{b}]}$} & \multicolumn{2}{|l|}{ RI lit. ${ }^{[c]}$} & \multirow[t]{2}{*}[\%]{$^{[\mathrm{d}]}$} & \multirow[t]{2}{*}{$\mathrm{ID}^{[\mathrm{e}]}$} \\
\hline & & & Adams & NIST08 & & \\
\hline 58 & trans-Cadina-1,4-diene & 1526 & 1534 & & 0.4 & $\mathrm{RI}, \mathrm{MS}$ \\
\hline 59 & Methyl dodecanoate & 1528 & 1525 & 1527 & 0.4 & $\mathrm{RI}, \mathrm{MS}$ \\
\hline 60 & (Z)-Nerolidol & 1533 & 1532 & & 0.3 & $\mathrm{RI}, \mathrm{MS}$ \\
\hline 62 & $\alpha$-Calacorene & 1536 & 1545 & 1547 & 0.2 & $\mathrm{RI}, \mathrm{MS}$ \\
\hline 63 & Elemol & 1545 & 1549 & 1545 & 2.3 & $\mathrm{RI}, \mathrm{MS}$ \\
\hline 64 & Germacrene B & 1547 & 1561 & 1548 & 2.2 & $\mathrm{RI}, \mathrm{MS}$ \\
\hline 65 & cis-Muurol-5-en- $4 \beta$-ol & 1554 & 1551 & & 0.1 & $\mathrm{RI}, \mathrm{MS}$ \\
\hline 66 & $\beta$-Calacorene & 1556 & 1564 & & 0.1 & $\mathrm{RI}, \mathrm{MS}$ \\
\hline 67 & cis-Muurol-5-en- $4 \alpha$-ol & 1559 & 1561 & & 0.1 & $\mathrm{RI}, \mathrm{MS}$ \\
\hline 72 & Salvial-4(14)-en-1-one & 1584 & 1594 & & 0.2 & $\mathrm{RI}, \mathrm{MS}$ \\
\hline 73 & Widdrol & 1588 & 1599 & 1587 & 0.3 & $\mathrm{Rl}, \mathrm{MS}$ \\
\hline 74 & Ethyl dodecanoate & 1597 & 1598 & 1597 & 0.2 & $\mathrm{RI}, \mathrm{MS}$ \\
\hline 75 & Humulene epoxide II & 1597 & 1608 & & 0.7 & $\mathrm{RI}, \mathrm{MS}$ \\
\hline 76 & 1,10-Di-epi-cubenol & 1620 & 1619 & & 5.1 & $\mathrm{Rl}, \mathrm{MS}$ \\
\hline 77 & epi- $\alpha$-Muurolol & 1635 & 1642 & & 1.4 & $\mathrm{RI}, \mathrm{MS}$ \\
\hline 78 & $\beta$-Eudesmol & 1640 & 1650 & 1640 & 1.2 & $\mathrm{RI}, \mathrm{MS}$ \\
\hline 79 & $\alpha$-Eudesmol & 1644 & 1653 & 1644 & 0.9 & $\mathrm{Rl}, \mathrm{MS}$ \\
\hline 80 & $\alpha$-Cadinol & 1647 & 1654 & 1646 & 1.2 & $\mathrm{RI}, \mathrm{MS}$ \\
\hline 81 & Shyobunol & 1680 & 1689 & & 3.4 & $\mathrm{RI}, \mathrm{MS}$ \\
\hline 82 & Amorpha-4,9-dien-2-ol & 1699 & 1700 & & 0.1 & $\mathrm{RI}, \mathrm{MS}$ \\
\hline 90 & ent-Manoyl oxide & 1976 & 1987 & 1977 & 5.5 & $\mathrm{RI}, \mathrm{MS}$ \\
\hline 91 & Abietatriene & 2042 & 2056 & 2041 & 0.5 & $\mathrm{RI}, \mathrm{MS}$ \\
\hline 92 & Abietadiene & 2065 & 2087 & & 0.1 & $\mathrm{RI}, \mathrm{MS}$ \\
\hline 93 & unknown diterpene $\mathrm{MW}=272$ & 2094 & & & 1.8 & MS \\
\hline 94 & Sandaracopimarinal & 2183 & 2184 & & 0.1 & $\mathrm{Rl}, \mathrm{MS}$ \\
\hline 95 & Sempervirol & 2282 & 2283 & & 0.1 & $\mathrm{RI}, \mathrm{MS}$ \\
\hline 96 & 4-epi-Abietal & 2295 & 2298 & & 0.4 & $\mathrm{RI}, \mathrm{MS}$ \\
\hline 97 & trans-Totarol & 2299 & 2314 & 2299 & 2.1 & $\mathrm{RI}, \mathrm{MS}$ \\
\hline 98 & trans-Ferruginol & 2325 & 2331 & 2325 & 0.2 & $\mathrm{RI}, \mathrm{MS}$ \\
\hline \multirow[t]{8}{*}{99} & Nonacosane & 2900 & 2900 & 2900 & 0.1 & Std \\
\hline & Total identified [\%] & & & & 91.0 & \\
\hline & Monoterpene hydrocarbons & & & & 1.3 & \\
\hline & Oxygenated monoterpenes & & & & 30.8 & \\
\hline & Sesquiterpene hydrocarbons & & & & 23.6 & \\
\hline & Oxygenated sesquiterpenes & & & & 21.7 & \\
\hline & Diterpenes & & & & 10.9 & \\
\hline & Others & & & & 4.5 & \\
\hline
\end{tabular}

${ }^{\text {[a] }}$ Compounds are listed in order of their elution from a HP-5MS column. ${ }^{[b]}$ Linear retention index on HP-5MS column, experimentally determined using homologous series of $C_{8}-C_{30}$ alkanes. ${ }^{[c]}$ Linear retention index taken from Adams (2007) and NIST 08 (2008). ${ }^{[d]}$ Percentage values are means of three determinations with a RSD\% in all cases below $10 \%$. ${ }^{\text {[e] }}$ Identification methods: std, based on comparison with authentic compounds; MS, based on comparison with Wiley, Adams and NIST 08 MS databases; $\mathrm{Rl}$, based on comparison of LRI with those reported in Adams, FFNSC 2 and NIST 08. ${ }^{[f]} \operatorname{tr}[\%]$ below $0.1 \%$. 
denomination of this taxon) from Portugal, Algeria and Morocco, where $\alpha$-pinene, $\beta$-phellandrene and $\alpha$-terpinyl acetate were detected as the major volatile compounds. ${ }^{[25][26][60]}$ On the other hand, in populations from Tunisia and Morocco $\alpha$-pinene was by far the most abundant volatile component. ${ }^{[14][28][29][61]}$ Thus, one of the main features which differentiated the investigated population of J. turbinata from those previously studied appears to be the low content of monoterpene hydrocarbons along with a noteworthy presence of sesquiterpenes and diterpenes.

Overall, it seems that J. phoenicea complex exhibits an infraspecific chemical variability with more chemotypes depending on geographic and climatic factors. The geographic isolation of the La Maddalena Archipelago could have influenced the development of the observed chemical variability. In fact, we have already detected peculiar molecular patterns in EOs obtained from species collected from these Isles, especially in the case of endemic entities as Artemisia caerulescens subsp. densiflora ${ }^{[62]}$ and Helichrysum microphyllum subsp. tyrrhenicum ${ }^{[63]}$ as well as in the case of more widespread species such as Artemisia arborescens. ${ }^{[64]}$

\section{Cytotoxic Activity on Tumor Cells}

The cytotoxic activity of essential oil and polar compounds $1-4,8$ and 9 from J. turbinata was evaluated on a selection of human tumor cell lines such as colon carcinoma, breast adenocarcinoma and malignant melanoma cell lines by MTT. Increasing concentrations of essential oil and polar compounds isolated from the ethanolic extract were assayed on the three tumor cell lines for $72 \mathrm{~h}$. The results showed that essential oil induced a concentration-dependent inhibitory effect on all cell lines tested in the dilutions range $1.56-400 \mu \mathrm{g} /$

Table 2. In vitro cytotoxic activity of Juniperus turbinata essential oil

\begin{tabular}{|c|c|c|c|}
\hline & \multicolumn{3}{|c|}{ Cell line $\left(I C_{50}[\mu \mathrm{g} / \mathrm{mL}]\right)^{[\mathrm{a}]}$} \\
\hline & MDA-MB $231^{[b]}$ & $\mathrm{A} 375^{[\mathrm{c}]}$ & $\mathrm{HCT} 116^{[\mathrm{d}]}$ \\
\hline \multicolumn{4}{|l|}{ Essential oil } \\
\hline J. turbinata & 33.69 & 9.48 & 25.10 \\
\hline $95 \%$ C.I. $^{[\mathrm{e}]}$ & $31.12-36.47$ & $7.83-11.49$ & $24.14-26.10$ \\
\hline \multicolumn{4}{|l|}{ Reference } \\
\hline Cisplatin & 3.56 & 0.56 & 2.68 \\
\hline 95\% C.I. & $2.90-3.75$ & $0.32-0.68$ & $2.17-2.96$ \\
\hline
\end{tabular}

$\mathrm{mL}$ (Table 2, Figure S1). The $\mathrm{IC}_{50}$ values were 9.48, 25.10, and $33.69 \mu \mathrm{g} / \mathrm{mL}$ towards A375, HCT116 and MDA-MB 231 cell line, respectively. The essential oil resulted active mainly on human melanoma cell line. The chemical composition of the essential oil does not put in evidence the presence of a main compound that could be responsible for the cytotoxic activity. $\alpha$-Terpineol $(11.0 \%)$ has been reported moderately cytotoxic towards Madin-Darby canine kidney (MDCK) cell line with $\mathrm{EC}_{50}$ values of $0.025 \%(\mathrm{v} / \mathrm{v}){ }^{[65]}$ Among other compounds present in the oil, minor components might also contribute to the cytotoxic activity being involved in some type of synergism with the major compounds.

The cytotoxic activity of compounds isolated from the ethanolic extract is reported in Table 3. Data showed a strong cytotoxic activity of imbricataloic acid (8) against all cell lines tested, with $\mathrm{IC}_{50}$ values of 0.06 , 0.114 , and $0.201 \mu \mathrm{m}$ against colon carcinoma, melanoma and breast adenocarcinoma cell lines, respectively (Figure S2). Noteworthy, its activity was higher than that of cisplatin used as positive control. Like in the case of essential oil, this compound showed the strongest effects on melanoma cells (nanomolar $I C_{50}$ values). Significant cytotoxic activity was also shown by cupressuflavone (9), but with lower intensity $\left(\mathrm{IC}_{50}\right.$ in the range of $12.71-19.25 \mu \mathrm{m}$; Figure S3) compared with that of imbricataloic acid (8), while the other purified compounds were inactive $\left(\mathrm{IC}_{50}>100 \mu \mathrm{M}\right)$.

The inhibitory properties of imbricatolic acid (1) on cell proliferation in several tumor cell lines have already been reported. ${ }^{[66]}$ In particular, at a concentration of $10 \mu \mathrm{m}$, imbricatolic acid (1) was able to arrest the cell cycle in p53-null CaLu-6 human lung tumor cells. New derivatives of imbricatolic acid were evaluated for antiproliferative activity on MRC-5, AGS, SKMES-1, J82 and HL-60 human tumor cell lines, with the most active compound showing an $I C_{50}$ value of $17 \mu \mathrm{m}$ on AGS cells. ${ }^{[67]}$ In our assay, imbricatolic acid (1) resulted inactive at the concentrations tested on all cell lines. However, the substitution of the primary alcoholic function at $\mathrm{C}(15)\left(\mathrm{CH}_{2} \mathrm{OH}\right.$ group) with an aldehydic function ( $\mathrm{CHO}$ group) in imbricataloic acid (8) structure seems to be a crucial structural feature to strongly enhance the cytotoxic activity of the diterpenoidic base skeleton. Therefore, it will be interesting to perform further studies in order to determine the mode of action, as well as the cytotoxicity against non-tumor cells, and in vivo efficacy of this diterpene.

\section{Antioxidant Activity}

In Table 4 is reported the antioxidant activity of J. turbinata essential oil against different radicals. 
Table 3. In vitro cytotoxic activity of diterpenoids and biflavonoids isolated from Juniperus turbinata

\begin{tabular}{|c|c|c|c|}
\hline Compound & \multicolumn{3}{|c|}{ Cell line $\left(I C_{50}[\mu \mathrm{M}]\right)^{[a]}$} \\
\hline $\begin{array}{l}\text { Imbricatolic acid (1) } \\
\text { 95\% C.I. }{ }^{[e]}\end{array}$ & $>100$ & $>100$ & $>100$ \\
\hline $\begin{array}{l}\text { 13-epi-Cupressic acid (2) } \\
\text { 95\% C.I. }\end{array}$ & $>100$ & $>100$ & $>100$ \\
\hline $\begin{array}{l}7 \alpha \text {-Hydroxysandaracopimaric acid (4) } \\
95 \% \text { C.I. }\end{array}$ & $>100$ & $>100$ & $>100$ \\
\hline Imbricataloic acid (8) & 0.201 & 0.114 & 0.060 \\
\hline 95\% C.I. & $0.173-0.234$ & $0.109-0.119$ & $0.055-0.066$ \\
\hline Cisplatin & 11.86 & 1.87 & 8.93 \\
\hline 95\% C.I. & $9.66-12.49$ & $1.07-2.26$ & $7.23-9.86$ \\
\hline
\end{tabular}

Table 4. In vitro radical scavenging activities of essential oil from Juniperus turbinata

\begin{tabular}{|c|c|c|c|c|c|}
\hline & \multicolumn{2}{|l|}{$\mathrm{DPPH}$} & \multicolumn{2}{|l|}{ ABTS $^{+}$} & $\begin{array}{l}\text { FRAP } \\
\text { TEAC }^{[a]} \\
{[\mu \mathrm{m} \text { TE/g] }}\end{array}$ \\
\hline \multicolumn{6}{|l|}{ Essential oil } \\
\hline $\begin{array}{l}\text { J. turbinata } \\
\text { Reference }\end{array}$ & $383.2 \pm 4.7$ & $110 \pm 1.5$ & $160.4 \pm 2.1$ & $90.2 \pm 4.2$ & $139.0 \pm 1.2$ \\
\hline
\end{tabular}

According to the DPPH and $\mathrm{ABTS}^{\circ}$ assays, the essential oil showed significant antioxidant activity with values of $\mathrm{IC}_{50}$ about 10 - and 25-fold lower when compared with Trolox, respectively. The measured reducing capacity power (FRAP assay), revealed that the oil has a moderate capacity for iron binding that is related to its possible action as peroxidation protector. The reducing power may be attributed to hydrogen donation from compounds bearing hydroxylic functions as well as to the presence of reductant agent. The latter can reduce the oxidized intermediates in lipid peroxidation processes, convert them to more stable products and, consequently, terminate radical chain reactions. By comparing the results (Figure S4) obtained by the three different antioxidant activity methods and the relationships between the chemical composition and the antioxidant activity, it seems that $J$. turbinata essential oil possesses a good capacity to scavenge free radicals and to prevent lipid peroxidation, which can be ascribed to the presence of hydroxylated compounds occurring among oxygen-containing monoterpenes, sesquiterpenes and diterpenes.

Table 5 and Figure $S 5$ show the scavenging activity of compounds $\mathbf{1}-\mathbf{4}, \mathbf{8}$ and $\mathbf{9}$ isolated from J. turbinata ethanol extract against the radicals $\mathrm{DPPH}$ and $\mathrm{ABTS}^{+}$and the evaluation of their reducing capacity power (FRAP). All tested compounds showed good scavenging ability towards the $\mathrm{ABTS}^{+}$radical, with an effectiveness in the order: cupressuflavone (9) > ent-manoyl oxide (3) > imbricatolic acid (1) $\equiv$ imbricataloic acid (8) $>7 \alpha$-hydroxysandaracopimaric 
Table 5. In vitro radical scavenging activities of isolated diterpenes and bioflavonoids from Juniperus turbinata

\begin{tabular}{|c|c|c|c|c|c|}
\hline Compound & \multicolumn{2}{|l|}{ DPPH } & \multicolumn{2}{|l|}{$\mathrm{ABTS}^{+}$} & $\begin{array}{l}\text { FRAP } \\
\text { TEAC }^{[a]} \\
{[\mu \mathrm{M} \mathrm{TE} / \mathrm{g}]}\end{array}$ \\
\hline \multicolumn{6}{|l|}{ Diterpenoids } \\
\hline Imbricatolic acid (1) & - & $>1000$ & $68 \pm 0.4$ & $79 \pm 2.0$ & $6 \pm 0.10$ \\
\hline 13-epi-Cupressic acid (2) & - & $>1000$ & $37 \pm 0.04$ & $146 \pm 9.8$ & $3 \pm 0.06$ \\
\hline Imbricataloic acid (8) & $17 \pm 0.1$ & $227 \pm 8.8$ & $62 \pm 0.3$ & $87 \pm 4.5$ & $10 \pm 0.17$ \\
\hline \multicolumn{6}{|l|}{ Biflavonoids } \\
\hline Cupressuflavone (9) & $211 \pm 0.1$ & $11 \pm 5.7$ & $2391 \pm 0.150$ & $1.35 \pm 0.18$ & $26 \pm 0.44$ \\
\hline \multicolumn{6}{|l|}{ Reference } \\
\hline Trolox & - & $1.22 \pm 0.07$ & - & $1.74 \pm 0.11$ & - \\
\hline
\end{tabular}

acid (4) > 13-epi-cupressic acid (2; Table 5). In particular, the strongest activity was observed for cupressuflavone $\left(\mathbf{9} ; \mathrm{IC} 501.35 \times 10^{-5} \mathrm{M}\right)$ which was even higher than that of the reference Trolox $\left(\mathrm{IC}_{50} 1.74 \times 10^{-5} \mathrm{M}\right)$. On the other hand, a negligible scavenging activity was observed against the DPPH radical. As a matter of fact, the compounds ent-manoyl oxide (3), imbricatolic acid (1) and 13-epi-cupressic acid (2) did not react with DPPH radical at all, whereas cupressuflavone (9) showed an activity that resulted 90 times lower than that of Trolox.

All the isolated compounds exhibited a moderate reducing capacity power measured with FRAP assay, with cupressuflavone (9) $>$ imbricataloic acid (8) > ent-manoyl oxide $(\mathbf{3})>$ imbricatolic acid $(\mathbf{1}) \equiv 7 \alpha$ hydroxysandaracopimaric acid (4) $>13$-epi-cupressic acid (2; Table 5).

Among the bioactive compounds identified in the J. turbinata ethanolic extract, the bioflavonoid cupressuflavone (9) seems to be important because of its broad spectrum of biological activities. ${ }^{[68]}$ Cupressuflavone (9) proved to be beneficial against oxidative stress by enhancing the antioxidant defense status, reducing lipid peroxidation and protecting against the pathological changes in the liver and kidney tissues. ${ }^{[69]}$ Moreover, it showed neutrophil elastase inhibitory activity ${ }^{[70]}$ and a potential osteoprotective effect. ${ }^{[71]}$ Although imbricatolic acid (1) did not show in our assays any notable antioxidant activity, it has been reported to control the cellular cycle progress. ${ }^{[66]}$ Its synthetic derivatives were proved to exert topical anti-inflammatory activity ${ }^{[72]}$ and to inhibit protein tyrosine phosphatase-1B. ${ }^{[73]}$ On the other hand, no information is currently available on the biological properties of imbricataloic acid (8).

\section{Conclusions}

The phytochemical investigations performed on the population of $J$. turbinata growing in La Maddalena Archipelago evidenced a significant rate of variability compared with other accessions of the same species. As a matter of fact, the essential oil was characterized by a new chemotype ( $\alpha$-terpineol-rich) which was not reported previously in other Mediterranean populations, whereas the ethanolic extract was the source of a new natural product (15-formyloxyimbricatolic acid (7)) and showed a phytochemical pattern quite different with respect to other Mediterranean populations, evidencing the influence of the isolated environment on the secondary metabolites expression. In addition, some of the isolated compounds, namely imbricataloic acid (8) and cupressoflavone (9), showed powerful cytotoxic and antioxidant activities, respectively. These findings support the traditional medical uses of the plant and encourage further studies for the development of plant-borne compounds formulations to be used in pharmaceutical and cosmetic applications.

\section{Experimental Section}

General

NMR spectra were recorded on a Varian Mercury $300 \mathrm{MHz}$ instrument and/or on a Bruker Avance III $400 \mathrm{MHz}$ instrument using $\mathrm{CDCl}_{3}, \mathrm{CD}_{3} \mathrm{OD}$ or $\left(\mathrm{D}_{6}\right) \mathrm{DMSO}$ as solvents; $\delta$ in ppm relative to $\mathrm{Me}_{4} \mathrm{Si}$ as internal standard, $J$ in $\mathrm{Hz}$. The internal solvent signal (m5) at $3.31 \mathrm{ppm}$ was set as reference for the spectra in $\mathrm{CD}_{3} \mathrm{OD}$, while the solvent signal ( $\mathrm{m} 5$ ) at $2.50 \mathrm{ppm}$ was set as reference for the spectra in $\left(D_{6}\right)$ DMSO. 


\section{Plant Material}

Aerial parts, including leaves and twigs of $J$. turbinata, were collected in La Maddalena Archipelago (Sardinia) at the beginning of July, 2014. The botanical identification was performed by one of us (M. B.). A voucher specimen (Herbarium CAG 1653/A) has been stored with the General Herbarium of the Department of Life and Environment Sciences, University of Cagliari, Italy.

\section{NMR and MS Experiments}

Bidimensional spectra were performed on a Bruker Avance III $400 \mathrm{MHz}$ instrument, operating at $9.4 \mathrm{~T}$ at 298 K. HSQC experiments were acquired with a spectral width of 15 and $250 \mathrm{ppm}$ for the proton and carbon, respectively, an average ${ }^{1} \mathrm{~J}(\mathrm{C}, \mathrm{H})$ value of $145 \mathrm{~Hz}$, a recycle delay of $2 \mathrm{~s}$ and a data matrix of $4 \mathrm{~K} \times 256$ points. HMBC experiments were acquired with a spectral width of 15 and $250 \mathrm{ppm}$ for the proton and carbon, respectively, a long range coupling constant of ${ }^{n} J(\mathrm{C}, \mathrm{H})$ value of $8 \mathrm{~Hz}$, a recycle delay of $2 \mathrm{~s}$ and a data matrix of $4 \mathrm{~K} \times 256$ points.

MS spectra were performed on a Q-TOF MICRO spectrometer (Waters, Manchester, UK) equipped with an ESI source that was operated in the negative and/ or positive ion mode. The flow rate of sample infusion was $10 \mu \mathrm{L} / \mathrm{min}$ with 100 acquisitions per spectrum. Data were analyzed using the MassLynx software developed by Waters.

Solvents of RPE grade were purchased from Sigma-Aldrich (Milan, Italy) or Carlo Erba Reagenti (Milan, Italy); silica gel 60 (70 - 230 mesh ASTM) was from Fluka.

\section{Ethanolic Extracts Analysis}

A portion of $260.1 \mathrm{~g}$ of fresh plant material, represented by leaves and terminal branches, was consecutively extracted with ethanol $96 \%$ (3 times, $48 \mathrm{~h}$ extraction, $2.5 \mathrm{~L}$ of solvent each extraction). Then, the extracts were filtered and the solvent evaporated under reduced pressure until an aqueous suspension was obtained. The suspension was frozen to $-20{ }^{\circ} \mathrm{C}$ and then lyophilized at the same temperature. A total amount of 21.3, 7.2 and $1.5 \mathrm{~g}$ of crude extract, respectively, was recovered. From the preliminary TLC screening, only the first and the second extract resulted most suitable for fractionation (the three extracts showed the same qualitative composition but the first and the second ones showed more intense spots in respect to the third one) and for this reason we worked on these ones. The first chromatographic separation was conducted on the second extract. A portion of $1.8 \mathrm{~g}$ of extract was partitioned over silica gel $(33.6 \mathrm{~g})$ using chloroform/methanol as eluting mixture, starting with 9:1 and gradually increasing the polarity to $8: 2$ during the chromatographic run. From this separation were recovered and identified the following diterpenoids: (Fr. 9A) imbricatolic acid (1) and 13-epi-cupressic acid (2) ${ }^{[52]}$ as a mixture (1:1; quantity not estimated); Fr. 21-23A, a low polar fraction, in which the presence of flavonoidic compounds was firstly evidenced on TLC by fluorescence to UV light and a yellow/orange reaction to $2 \mathrm{~N} \mathrm{H}_{2} \mathrm{SO}_{4}$ reagent after heating at $120{ }^{\circ} \mathrm{C}$. This fraction resulted also positive to $\mathrm{FeCl}_{3}$ reagent. NMR analysis on Fr. 21-22A $(39.6 \mathrm{mg})$ revealed the presence of cupressuflavone (9), ${ }^{[33][74]}$ a symmetric $8,8^{\prime}$ dimer of apigenin, as principal component, together with minor amounts of amentoflavone $(\mathbf{1 0})^{[75]}$ and hinokiflavone $(\mathbf{1 1})^{[53]}$ (4:2:1); Fr. 23A (18.8 mg) contained cupressuflavone (9) as a quite pure compound.

A portion of the first extract (1.7 g) was partitioned on silica gel $(39.3 \mathrm{~g})$ using $\mathrm{BuOH}$ saturated with water $(82: 18, v / v)$ as first eluting mixture. From this first separation, a less polar fraction (Fr. 2-5B; $0.870 \mathrm{~g}$ ) was recovered. This fraction was further partitioned on silica gel $(36.0 \mathrm{~g})$ using chloroform/methanol as eluting mixture, starting with $98: 2$ and gradually increasing the polarity to 9:1. According to elution order were obtained the following fractions: (Fr. 14-16C) ent-manoyl oxide $(3)^{[76]}(18.3 \mathrm{mg}),(\mathrm{Fr} .32-33 \mathrm{C})$ a mixture of terpenoids (145.2 mg), (Fr. 35-37C) imbricatolic acid (1; $20.6 \mathrm{mg}$ ), (Fr. 65-66C) 7 $\alpha$-hydroxysandaracopimaric acid $(4)^{[77]}(10.7 \mathrm{mg})$. The mixture of terpenoids (Fr. 32-33C; $145.2 \mathrm{mg}$ ) was further chromatographed on $\mathrm{SiO}_{2}$ column chromatography $(5.0 \mathrm{~g})$ starting the elution with chloroform and then increased the polarity during the chromatographic run to $99: 1$ with methanol $(\mathrm{v} / \mathrm{v})$. In this manner, the presence of the following diterpenoids was recognized: 13-epi-torusolal $(5){ }^{[54][78]}$ sandaracopimaric acid $(6)^{[77]}$ and 15-formyloxyimbricatolic acid (7) ${ }^{[38]}$ as a mixture (4:3:2; Fr. 34D; $4.3 \mathrm{mg}$ ), imbricataloic acid (8) ${ }^{[16]}$ (Fr. 38-39D; $8.3 \mathrm{mg}$ ), and 13-epi-cupressic acid (2; Fr. 61-64D; 5.6 mg). All the isolated compounds were identified by comparison of the obtained experimental data with those available in literature.

Imbricatolic Acid (1). ${ }^{1} \mathrm{H}-\mathrm{NMR}\left(300 \mathrm{MHz}, \mathrm{CDCl}_{3}\right)$ : $4.82\left(s, \mathrm{H}_{\mathrm{a}}-\mathrm{C}(17)\right), 4.48\left(s, \mathrm{H}_{\mathrm{b}}-\mathrm{C}(17)\right), 3.67\left(d d,{ }^{2} \mathrm{~J}(\mathrm{H}\right.$, $\left.\mathrm{H})_{\text {gem }}=12.8,{ }^{3} \mathrm{~J}(\mathrm{H}, \mathrm{H})=6.4, \mathrm{H}-\mathrm{C}(15)\right), 2.40$ (br. $d,{ }^{2} \mathrm{~J}(\mathrm{H}$, $\left.\mathrm{H})_{\text {gem }}=10.5, \mathrm{H}_{\mathrm{a}}-\mathrm{C}(7)\right) 2.16\left(\right.$ br. $d,{ }^{2} J(\mathrm{H}, \mathrm{H})_{\text {gem }}=10.5$, $\left.\mathrm{H}_{\mathrm{b}}-\mathrm{C}(7)\right), \quad 1.23(\mathrm{~s}, \mathrm{Me}(18)), 0.89 \quad\left(d,{ }^{3} J(\mathrm{H}, \mathrm{H})=6.2\right.$, $\mathrm{Me}(16)), 0.58$ (s, $\mathrm{Me}(20)) .{ }^{13} \mathrm{C}-\mathrm{NMR}\left(100 \mathrm{MHz}, \mathrm{CDCl}_{3}\right)$ : $183.3(\mathrm{COOH}) ; 148.2(\mathrm{C}(8)) ; 106.4 \quad\left(\mathrm{CH}_{2}(17)\right) ; 61.2$ 
$\left(\mathrm{CH}_{2}(15)\right) ; 56.6(\mathrm{CH}(5)) ; 56.3(\mathrm{CH}(9)) ; 44.1(\mathrm{C}(4)) ; 40.5$ $(\mathrm{C}(10)) ; 39.5\left(\mathrm{CH}_{2}(12)\right) ; 39.1 \quad\left(\mathrm{CH}_{2}(1)\right) ; 38.7\left(\mathrm{CH}_{2}(14)\right)$; $38.0 \quad\left(\mathrm{CH}_{2}(7)\right) ; \quad 36.4 \quad\left(\mathrm{CH}_{2}(3)\right) ; \quad 30.2 \quad(\mathrm{CH}(13)) ; \quad 29.0$ $(\mathrm{Me}(18)) ; 26.0\left(\mathrm{CH}_{2}(6)\right) ; 21.1\left(\mathrm{CH}_{2}(11)\right) ; 19.9\left(\mathrm{CH}_{2}(2)\right)$; 19.8 (Me(16)) 12.7 (Me(20)). ESI-MS: $320.80\left([\mathrm{M}-\mathrm{H}]^{-}\right)$.

13-epi-Cupressic Acid (2). ${ }^{1} \mathrm{H}-\mathrm{NMR},(400 \mathrm{MHz}$, $\left.\mathrm{CDCl}_{3}\right): 5.90\left(d d,{ }^{3} J(\mathrm{H}, \mathrm{H})_{\text {trans }}=17.4,{ }^{3} \mathrm{~J}(\mathrm{H}, \mathrm{H})_{\text {cis }}=10.8\right.$, $\mathrm{H}-\mathrm{C}(14)), 5.20\left(d d,{ }^{3} J(\mathrm{H}, \mathrm{H})_{\text {trans }}=17.4,{ }^{2} J(\mathrm{H}, \mathrm{H})_{\text {gem }}=1.2\right.$, $\left.\mathrm{H}_{\mathrm{a}}-\mathrm{C}(15)\right), 5.06\left(d d,{ }^{3} \mathrm{~J}(\mathrm{H}, \mathrm{H})_{\text {cis }}=10.8,{ }^{2} J(\mathrm{H}, \mathrm{H})_{\text {gem }}=1.2\right.$, $\left.\mathrm{H}_{\mathrm{b}}-\mathrm{C}(15)\right), 4.83$ (br. $\left.s, \mathrm{H}_{\mathrm{a}}-\mathrm{C}(17)\right), 4.49$ (br. $s, \mathrm{H}_{\mathrm{b}}-\mathrm{C}(17)$ ), $2.39\left(d d,{ }^{2} J(\mathrm{H}, \mathrm{H})_{\text {gem }}=10.6,{ }^{3} J(\mathrm{H}, \mathrm{H})=2.7, \mathrm{H}_{\mathrm{a}}-\mathrm{C}(7)\right), 2.00$ (br. $\left.d,{ }^{3} J(\mathrm{H}, \mathrm{H})=10.6, \mathrm{H}_{\mathrm{b}}-\mathrm{C}(7)\right), 1.27(\mathrm{~s}, \mathrm{Me}(18)), 1.23(\mathrm{~s}$, $\mathrm{Me}(16)), 0.59(s, \mathrm{Me}(20)) .{ }^{13} \mathrm{C}-\mathrm{NMR}\left(\mathrm{CDCl}_{3}, 100 \mathrm{MHz}\right)$ : $183.26(\mathrm{COOH}) ; 148.21(\mathrm{C}(8)) ; 145.11(\mathrm{CH}(14)) ; 111.86$ $\left(\mathrm{CH}_{2}(15)\right) ; 106.67\left(\mathrm{CH}_{2}(17)\right) ; 73.88(\mathrm{C}(13)) ; 56.64(\mathrm{CH}(5))$; $56.48(\mathrm{CH}(9)) ; 44.29 \quad(\mathrm{C}(4)) ; 41.48 \quad\left(\mathrm{CH}_{2}(12)\right) ; 40.69$ $(\mathrm{C}(10)) ; 39.26\left(\mathrm{CH}_{2}(1)\right) ; 38.86\left(\mathrm{CH}_{2}(7)\right) ; 36.53\left(\mathrm{CH}_{2}(3)\right)$; 29.29 (Me(18)); 28.23 (Me(16)); 26.21 (CH2(6)); 20.13 $\left(\mathrm{CH}_{2}(2)\right) ; 18.04\left(\mathrm{CH}_{2}(11)\right) ; 12.89$ (Me(20)). ESI-MS: 318.78 $\left([\mathrm{M}-\mathrm{H}]^{-}\right)$.

ent-Manoyl Oxide (3). ${ }^{1} \mathrm{H}-\mathrm{NMR},\left(300 \mathrm{MHz}, \mathrm{CDCl}_{3}\right)$ : $5.88\left(d d,{ }^{3} J(\mathrm{H}, \mathrm{H})_{\text {trans }}=17.3,{ }^{3} \mathrm{~J}(\mathrm{H}, \mathrm{H})_{\text {cis }}=10.8, \mathrm{H}-\mathrm{C}(14)\right)$, $5.14\left(d,{ }^{3} J(\mathrm{H}, \mathrm{H})_{\text {trans }}=17.3, \mathrm{H}_{\mathrm{a}}-\mathrm{C}(15)\right), 4.92\left(d,{ }^{3} J(\mathrm{H}\right.$, $\left.\mathrm{H})_{c i s}=10.8, \mathrm{H}_{\mathrm{b}}-\mathrm{C}(15)\right), 1.83\left(d,{ }^{2} J(\mathrm{H}, \mathrm{H})_{\mathrm{gem}}=12.3, \mathrm{H}-\right.$ $\mathrm{C}(7)), 1.29(\mathrm{~s}, \mathrm{Me}(16)), 1.27(\mathrm{~s}, \mathrm{Me}(17)), 1.25(s, \mathrm{Me}(20))$, 0.86 (s, Me(19)), 0.79 (s, Me(18)). ${ }^{13} \mathrm{C}-\mathrm{NMR}(75 \mathrm{MHz}$, $\left.\mathrm{CDCl}_{3}\right): 147.9(\mathrm{CH}(14)), 110.2\left(\mathrm{CH}_{2}(15)\right), 75.1(\mathrm{C}(8)), 73.2$ $(\mathrm{C}(13)), 56.4(\mathrm{CH}(9)), 55.6(\mathrm{CH}(5)), 43,2\left(\mathrm{CH}_{2}(7)\right), 42.1$ $\left(\mathrm{CH}_{2}(3)\right), 39.00\left(\mathrm{CH}_{2}(1)\right), 35.7\left(\mathrm{CH}_{2}(12)\right), 33.3(\mathrm{Me}(16))$, $33.2(\mathrm{C}(10)), 29.7(\mathrm{Me}(19)), 28.5(\mathrm{C}(4)), 25.5\left(\mathrm{CH}_{2}(1)\right)$, $21.33(\mathrm{Me}(18)), 19.9\left(\mathrm{CH}_{2}(6)\right), 18.5\left(\mathrm{CH}_{2}(2)\right), 15.4$ $\left(\mathrm{CH}_{2}(11)\right), 15.2(\mathrm{Me}(20))$. ESI-MS: $313.21\left([\mathrm{M}+\mathrm{Na}]^{+}\right)$.

7 $\alpha$-Hydroxysandaracopimaric Acid (4). ${ }^{1} \mathrm{H}-\mathrm{NMR}$ $\left(300 \mathrm{MHz}, \mathrm{CDCl}_{3}\right): 5.76\left(d d,{ }^{3} J(\mathrm{H}, \mathrm{H})_{\text {trans }}=17.4,{ }^{3} J(\mathrm{H}\right.$, $\left.\mathrm{H})_{\text {cis }}=10.6, \mathrm{H}-\mathrm{C}(15)\right), 5.52$ (br. $\left.\mathrm{s}, \mathrm{H}-\mathrm{C}(14)\right), 4.98-4.87$ $(m, \mathrm{H}-\mathrm{C}(16)), 4.22$ (br. s, $\mathrm{H}-\mathrm{C}(7)), 2.40$ (br. $d,{ }^{3} \mathrm{~J}(\mathrm{H}$, $\left.\mathrm{H})=10.5, \mathrm{H}_{\mathrm{a}}-\mathrm{C}(12)\right), 2.19$ (br. $d,{ }^{3} J(\mathrm{H}, \mathrm{H})=10.5, \mathrm{H}_{\mathrm{b}}-$ $\mathrm{C}(12)), 1.18$ (s, Me(19)), 1.03 (s, Me(17)), 0.80 (s, Me (20)). ${ }^{13} \mathrm{C}-\mathrm{NMR}\left(75 \mathrm{MHz}, \mathrm{CDCl}_{3}\right): 182.88(\mathrm{COOH}) ; 147.89$ $(\mathrm{CH}(15)) ; \quad 138.33 \quad(\mathrm{C}(8)) ; \quad 134.71 \quad(\mathrm{CH}(14)) ; 110.88$ $\left(\mathrm{CH}_{2}(16)\right) ; 73.12(\mathrm{CH}(7)) ; 46.66(\mathrm{C}(4)) ; 46.03(\mathrm{CH}(9))$; $41.77(\mathrm{CH}(5)) ; \quad 38.09 \quad\left(\mathrm{CH}_{2}(1)\right) ; 37.91 \quad(\mathrm{C}(10)) ; 37.38$ $(\mathrm{C}(13)) ; 36.76\left(\mathrm{CH}_{2}(3)\right) ; 34.09\left(\mathrm{CH}_{2}(12)\right) ; 31.47\left(\mathrm{CH}_{2}(6)\right)$; 25.65 (Me(17)); $18.07\left(\mathrm{CH}_{2}(11)\right) ; 18.01\left(\mathrm{CH}_{2}(2)\right) ; 16.71$ (Me(19)); 14.45 (Me(20)). ESI-MS: $317.18\left([\mathrm{M}-\mathrm{H}]^{-}\right)$.

13-epi-Torulosal (5). ${ }^{1} \mathrm{H}-\mathrm{NMR}$ (400 $\left.\mathrm{MHz}, \mathrm{CDCl}_{3}\right)$ : $9.75\left(d,{ }^{3} J(\mathrm{H}, \mathrm{H})=1.4, \mathrm{H}-\mathrm{C}(19)\right), 5.91\left(d d,{ }^{3} \mathrm{~J}(\mathrm{H}, \mathrm{H})_{\text {trans }}=\right.$ $\left.17.3,{ }^{3} \mathrm{~J}(\mathrm{H}, \mathrm{H})_{\text {cis }}=10.7, \mathrm{H}-\mathrm{C}(14)\right), 5.21\left(d d,{ }^{3} \mathrm{~J}(\mathrm{H}, \mathrm{H})_{\text {trans }}=\right.$ $\left.17.3,{ }^{2} J(\mathrm{H}, \mathrm{H})_{\text {gem }}=1.3, \mathrm{H}_{\mathrm{a}}-\mathrm{C}(15)\right), 5.07\left(d d,{ }^{3} \mathrm{~J}(\mathrm{H}, \mathrm{H})_{\text {trans }}=\right.$ $\left.10.7,{ }^{2} \mathrm{~J}(\mathrm{H}, \mathrm{H})_{\text {gem }}=1.3, \mathrm{H}_{\mathrm{b}}-\mathrm{C}(15)\right), 4.87 \quad\left(s, \mathrm{H}_{\mathrm{a}}-\mathrm{C}(17)\right)$, $4.53\left(s, H_{b}-C(17)\right), 1.28(s, \operatorname{Me}(16)), 1.02$ (s, $\left.\operatorname{Me}(18)\right)$, 0.57 (s, Me(20)). ${ }^{13} \mathrm{C}-\mathrm{NMR}\left(100 \mathrm{MHz}, \mathrm{CDCl}_{3}\right): 205.75$ $(\mathrm{CHO}), 147.50(\mathrm{C}(8)), 144.98(\mathrm{CH}(14)), 111.76\left(\mathrm{CH}_{2}(15)\right)$,
$107.36\left(\mathrm{CH}_{2}(17)\right), 73.62(\mathrm{C}(13)), 56.13(\mathrm{CH}(9)), 55.87$ $(\mathrm{CH}(5)), 48.66(\mathrm{C}(4)), 41.26\left(\mathrm{CH}_{2}(12)\right), 40.55(\mathrm{C}(10))$, $38.49\left(\mathrm{CH}_{2}(7)\right), 38.46\left(\mathrm{CH}_{2}(3)\right), 34.47\left(\mathrm{CH}_{2}(1)\right), 28.14$ $(\mathrm{Me}(16)), \quad 24.38 \quad(\mathrm{Me}(18)), \quad 24.08 \quad\left(\mathrm{CH}_{2}(\mathrm{C} 6)\right), \quad 19.28$ $\left(\mathrm{CH}_{2}(2)\right), 17.97\left(\mathrm{CH}_{2}(11)\right), 13.54$ (Me(20)). ESI-MS: 303.21 $\left([\mathrm{M}-\mathrm{H}]^{-}\right), 327.27\left([\mathrm{M}+\mathrm{Na}]^{+}\right)$.

Sandaracopimaric Acid (6). ${ }^{1} \mathrm{H}-\mathrm{NMR}(400 \mathrm{MHz}$, $\left.\mathrm{CDCl}_{3}\right): 5.78\left(d d,{ }^{3} \mathrm{~J}(\mathrm{H}, \mathrm{H})_{\text {trans }}=17.4,{ }^{3} \mathrm{~J}(\mathrm{H}, \mathrm{H})_{\text {cis }}=10.5\right.$, $\mathrm{H}-\mathrm{C}(15)), 5.23(\mathrm{~s}, \mathrm{H}-\mathrm{C}(14)), 4.92\left(d d,{ }^{3} \mathrm{~J}(\mathrm{H}, \mathrm{H})_{\text {trans }}=17.4\right.$, $\left.{ }^{2} J(\mathrm{H}, \mathrm{H})_{\text {gem }}=1.4, \mathrm{H}_{\mathrm{a}}-\mathrm{C}(16)\right), 4.89\left(d d,{ }^{3} \mathrm{~J}(\mathrm{H}, \mathrm{H})_{\text {cis }}=10.5\right.$, $\left.{ }^{2} \mathrm{~J}(\mathrm{H}, \mathrm{H})_{\text {gem }}=1.4, \mathrm{H}_{\mathrm{b}}-\mathrm{C}(16)\right), 1.24(\mathrm{~s}, \mathrm{Me}(19)), 1.06$ ( $\mathrm{s}$, $\mathrm{Me}(17)), 0.86$ (s, $\mathrm{Me}(20)) .{ }^{13} \mathrm{C}-\mathrm{NMR}\left(100 \mathrm{MHz}, \mathrm{CDCl}_{3}\right)$ : $180.24(\mathrm{COOH}), 148.18(\mathrm{CH}(15)), 136.60(\mathrm{C}(8)), 129.14$ $(\mathrm{CH}(14)), 110.15\left(\mathrm{CH}_{2}(16)\right), 50.58(\mathrm{CH}(9)), 48.93(\mathrm{CH}(5))$, $47.17(\mathrm{C}(4)), 38.30\left(\mathrm{CH}_{2}(1)\right), 37.75(\mathrm{C}(10)), 37.40(\mathrm{C}(13))$, $37.00\left(\mathrm{CH}_{2}(3)\right), 35.47\left(\mathrm{CH}_{2}(7)\right), 34.46\left(\mathrm{CH}_{2}(12)\right), 26.08$ (Me(17)), $24.89\left(\mathrm{CH}_{2}(6)\right), 18.57\left(\mathrm{CH}_{2}(11)\right), 18.15\left(\mathrm{CH}_{2}(2)\right)$, 16.87 (Me(19)), $15.21 \quad$ (Me(20)). $\quad$ ESI-MS: 301.17 $\left([\mathrm{M}-\mathrm{H}]^{-}\right) ; 325.12\left([\mathrm{M}+\mathrm{Na}]^{+}\right)$.

15-Formyloxyimbricatolic Acid (7). ${ }^{1} \mathrm{H}-\mathrm{NMR}$ (400 MHz, CDCl $): 8.06(s, \mathrm{H}-\mathrm{C}(21)), 4.85\left(s, \mathrm{H}_{\mathrm{a}}-\mathrm{C}(17)\right)$, $4.49\left(s, \mathrm{H}_{\mathrm{b}}-\mathrm{C}(17)\right), 4.22-4.17(m, \mathrm{H}-\mathrm{C}(15)), 1.25(s$, $\mathrm{Me}(19)), 0.93\left(d,{ }^{3} J(\mathrm{H}, \mathrm{H})=6.5, \mathrm{Me}(16)\right), 0.62(s, \mathrm{Me}(20))$. ${ }^{13} \mathrm{C}-\mathrm{NMR}\left(100 \mathrm{MHz}, \mathrm{CDCl}_{3}\right): 181.37(\mathrm{COOH}), 161.19$ (HCOO), $\quad 148.90 \quad(\mathrm{C}(8)), \quad 106.41 \quad\left(\mathrm{CH}_{2}(17)\right), \quad 62.53$ $\left(\mathrm{CH}_{2}(15)\right), 56.59(\mathrm{CH}(5)), 56.32(\mathrm{CH}(9)), 44.09(\mathrm{C}(4))$, $40.54(\mathrm{C}(10)), 39.15\left(\mathrm{CH}_{2}(1)\right), \quad 38.74\left(\mathrm{CH}_{2}(7)\right), 38.11$ $\left(\mathrm{CH}_{2}(3)\right), \quad 36.06 \quad\left(\mathrm{CH}_{2}(12)\right), \quad 35.14 \quad\left(\mathrm{CH}_{2}(14)\right), \quad 30.49$ ( $\mathrm{CH}(13)), 29.01(\mathrm{Me}(18)), 26.03\left(\mathrm{CH}_{2}(6)\right), 21.08\left(\mathrm{CH}_{2}(11)\right)$, $19.93\left(\mathrm{CH}_{2}(2)\right), 19.63(\mathrm{Me}(16)), 12.82(\mathrm{Me}(20))$. ESI-MS: $349.18\left([\mathrm{M}-\mathrm{H}]^{-}\right) ; 373.13\left([\mathrm{M}+\mathrm{Na}]^{+}\right)$.

Imbricataloic Acid (8). ${ }^{1} \mathrm{H}-\mathrm{NMR},\left(300 \mathrm{MHz}, \mathrm{CDCl}_{3}\right)$ : $9.75\left(t,{ }^{3} J(\mathrm{H}, \mathrm{H})=2.3, \mathrm{H}-\mathrm{C}(15)\right), 4.84$ (br. $\left.s, \mathrm{H}_{\mathrm{a}}-\mathrm{C}(17)\right)$, 4.47 (br. $\left.s, \mathrm{H}_{\mathrm{b}}-\mathrm{C}(17)\right), 1.25(s, \mathrm{Me}(19)), 0.97\left(d,{ }^{3} J(\mathrm{H}\right.$, $\mathrm{H})=6.7, \mathrm{H}-\mathrm{C}(16)), 0.60(\mathrm{~s}, \mathrm{Me}(20)) .{ }^{13} \mathrm{C}-\mathrm{NMR}(100 \mathrm{MHz}$, $\left.\mathrm{CDCl}_{3}\right): 203.3(\mathrm{CHO}), 182.3(\mathrm{COOH}), 148.21(\mathrm{C}(8)), 106.6$ $\left(\mathrm{CH}_{2}(17)\right), 56.61(\mathrm{CH}(9)), 56.46(\mathrm{CH}(5)), 50.99\left(\mathrm{CH}_{2}(14)\right)$, $44.28 \quad(\mathrm{C}(4)), \quad 40.70 \quad(\mathrm{C}(10)), \quad 39.31 \quad\left(\mathrm{CH}_{2}(1)\right), \quad 38.87$ $\left(\mathrm{CH}_{2}(7)\right), 38.19\left(\mathrm{CH}_{2}(3)\right), 36.28(\mathrm{CH}(13)), 29.15(\mathrm{Me}(19))$, $29.04\left(\mathrm{CH}_{2}(12)\right), 26.21\left(\mathrm{CH}_{2}(6)\right), 21.37\left(\mathrm{CH}_{2}(11)\right), 20.33$ (Me(16)), $20.06\left(\mathrm{CH}_{2}(2)\right), 12.93$ (Me(20)). ESI-MS: 319.26 $\left([\mathrm{M}-\mathrm{H}]^{-}\right)$.

Cupressuflavone (9). ${ }^{1} \mathrm{H}-\mathrm{NMR}\left(300 \mathrm{MHz}, \mathrm{CD}_{3} \mathrm{OD}\right)$ : $7.48\left(d^{3}{ }^{3} \mathrm{~J}(\mathrm{H}, \mathrm{H})=8.6, \mathrm{H}-\mathrm{C}\left(2^{\prime}\right), \mathrm{H}-\mathrm{C}\left(6^{\prime}\right), \mathrm{H}-\mathrm{C}\left(2^{\prime \prime \prime}\right), \mathrm{H}-\mathrm{C}\left(6^{\prime \prime \prime}\right)\right)$, $6.75\left(d^{3} \mathrm{~J}(\mathrm{H}, \mathrm{H})=8.6, \mathrm{H}-\mathrm{C}\left(3^{\prime}\right), \mathrm{H}-\mathrm{C}\left(5^{\prime}\right), \mathrm{H}-\mathrm{C}\left(3^{\prime \prime \prime}\right), \mathrm{H}-\mathrm{C}\left(5^{\prime \prime \prime}\right)\right)$, $6.60\left(s, \mathrm{H}-\mathrm{C}(3), \mathrm{H}-\mathrm{C}\left(3^{\prime \prime}\right)\right), 6.48\left(\mathrm{~s}, \mathrm{H}-\mathrm{C}(6), \mathrm{H}-\mathrm{C}\left(6^{\prime \prime}\right)\right) .{ }^{1} \mathrm{H}-$ NMR (300 MHz, (D $)$ DMSO): 10.32 (br. s, 7-OH), 7.50 (d, $\left.{ }^{3} \mathrm{~J}(\mathrm{H}, \mathrm{H})=8.8, \mathrm{H}-\mathrm{C}\left(2^{\prime}\right), \mathrm{H}-\mathrm{C}\left(6^{\prime}\right), \mathrm{H}-\mathrm{C}\left(2^{\prime \prime \prime}\right), \mathrm{H}-\mathrm{C}\left(6^{\prime \prime \prime}\right)\right), 6.80(\mathrm{~s}$, $\left.\mathrm{H}-\mathrm{C}(3), \mathrm{H}-\mathrm{C}\left(3^{\prime \prime}\right)\right), 6.74\left(d^{3} \mathrm{~J}(\mathrm{H}, \mathrm{H})=8.8, \mathrm{H}-\mathrm{C}\left(3^{\prime}\right), \mathrm{H}-\mathrm{C}\left(5^{\prime}\right)\right.$, $\left.\mathrm{H}-\mathrm{C}\left(3^{\prime \prime \prime}\right), \mathrm{H}-\mathrm{C}\left(5^{\prime \prime \prime}\right)\right), 6.46\left(5, \mathrm{H}-\mathrm{C}(6), \mathrm{H}-\mathrm{C}\left(6^{\prime \prime}\right)\right) .{ }^{13} \mathrm{C}-\mathrm{NMR}$ (75 MHz, CD $\left.{ }_{3} \mathrm{OD}\right): 184.30\left(\mathrm{C}(4)=\mathrm{O}, \mathrm{C}\left(4^{\prime \prime}\right)=\mathrm{O}\right), 166.11(\mathrm{C}(7)$, $\left.C\left(7^{\prime}\right)\right), 164.22\left(C(2), C\left(2^{\prime \prime}\right)\right), 162.91\left(C\left(4^{\prime}\right), C\left(4^{\prime \prime \prime}\right)\right), 162.62$ $\left(C(5), C\left(5^{\prime \prime}\right)\right), 156.96\left(C(9), C\left(9^{\prime \prime}\right)\right), 129.16\left(\mathrm{CH}\left(2^{\prime}\right), \mathrm{CH}\left(2^{\prime \prime \prime}\right)\right.$, 
$\left.\mathrm{CH}\left(6^{\prime}\right), \mathrm{CH}\left(6^{\prime \prime \prime}\right)\right), 123.15\left(\mathrm{C}\left(1^{\prime}\right), \mathrm{C}\left(1^{\prime \prime \prime}\right)\right), 116.87\left(\mathrm{CH}\left(3^{\prime}\right), \mathrm{CH}\right.$ $\left.\left(3^{\prime \prime \prime}\right), \mathrm{CH}\left(5^{\prime}\right), \mathrm{CH}\left(5^{\prime \prime \prime}\right)\right), 105.60\left(\mathrm{C}(10), \mathrm{C}\left(10^{\prime \prime}\right)\right), 103.44(\mathrm{CH}(3)$, $\left.\mathrm{CH}\left(3^{\prime \prime}\right)\right), 99.94\left(\mathrm{C}(8), \mathrm{C}\left(8^{\prime}\right)\right), 99.83\left(\mathrm{CH}(6), \mathrm{CH}\left(6^{\prime \prime}\right)\right)$. ESI-MS: $536.79\left([\mathrm{M}-\mathrm{H}]^{-}\right)$.

Amentoflavone (10). ${ }^{1} \mathrm{H}-\mathrm{NMR}\left(300 \mathrm{MHz}, \mathrm{CD}_{3} \mathrm{OD}\right)$ : 7.93 (br. s, $\left.\mathrm{H}-\mathrm{C}\left(2^{\prime}\right)\right), 7.92$ (br. $d^{3} \mathrm{~J}(\mathrm{H}, \mathrm{H})=9.0, \mathrm{H}-\mathrm{C}\left(6^{\prime}\right)$ ), 7.51* (br. $\left.d,{ }^{3} J(\mathrm{H}, \mathrm{H})=8.8, \mathrm{H}-\mathrm{C}\left(2^{\prime \prime \prime}\right), \mathrm{H}-\mathrm{C}\left(6^{\prime \prime \prime}\right)\right), 7.48^{*}$ (br. $d,{ }^{3} J(\mathrm{H}, \mathrm{H})=9.0, \mathrm{H}-\mathrm{C}\left(5^{\prime}\right)$ ), 7.13 (br. $d^{3}{ }^{3} J(\mathrm{H}, \mathrm{H})=8.7$, $\left.\mathrm{H}-\mathrm{C}\left(3^{\prime \prime \prime}\right), \mathrm{H}-\mathrm{C}\left(5^{\prime \prime \prime}\right)\right), 6.70\left(\mathrm{~s}, \mathrm{H}-\mathrm{C}\left(3^{\prime \prime}\right)\right), 6.62(s, \mathrm{H}-\mathrm{C}(3))$, $6.41\left(d,{ }^{4} J(\mathrm{H}, \mathrm{H})=1.6, \mathrm{H}-\mathrm{C}(8)\right), 6.39\left(s, \mathrm{H}-\mathrm{C}\left(6^{\prime \prime}\right)\right), 6.19(d$, $\left.{ }^{4} J(\mathrm{H}, \mathrm{H})=1.6, \mathrm{H}-\mathrm{C}(6)\right)$; * partially overlapped signals. ESI-MS: $536.99\left([\mathrm{M}-\mathrm{H}]^{-}\right) ; 539.05\left([\mathrm{M}+\mathrm{H}]^{+}\right)$.

Hinokiflavone (11). ${ }^{1} \mathrm{H}-\mathrm{NMR}\left(300 \mathrm{MHz}, \mathrm{CD}_{3} \mathrm{OD}\right)$ : 7.92* (br. $d,{ }^{3} J(\mathrm{H}, \mathrm{H})=8.9, \mathrm{H}-\mathrm{C}\left(3^{\prime}\right), \mathrm{H}-\mathrm{C}\left(5^{\prime}\right), \mathrm{H}-\mathrm{C}\left(2^{\prime \prime \prime}\right)$, $\left.\mathrm{H}-\mathrm{C}\left(6^{\prime \prime \prime}\right)\right), 7.13-6.98^{*}\left(m, \mathrm{H}-\mathrm{C}\left(2^{\prime}\right), \mathrm{H}-\mathrm{C}\left(6^{\prime}\right), \mathrm{H}-\mathrm{C}\left(3^{\prime \prime \prime}\right)\right.$, $\left.\mathrm{H}-\mathrm{C}\left(5^{\prime \prime \prime}\right)\right), 6.86(\mathrm{~s}, \mathrm{H}-\mathrm{C}(3)), 6.76\left(\mathrm{~s}, \mathrm{H}-\mathrm{C}\left(3^{\prime \prime}\right)\right), 6.73(\mathrm{~s}, \mathrm{H}-$ $\left.\mathrm{C}\left(8^{\prime \prime}\right)\right), 6.48$ (br. $\left.s, \mathrm{H}-\mathrm{C}(8)\right), 6.19$ (br. $\left.s, \mathrm{H}-\mathrm{C}\left(6^{\prime \prime}\right)\right)$; * partially overlapped signals. ESI-MS: $536.99\left([\mathrm{M}-\mathrm{H}]^{-}\right)$; $539.05\left([\mathrm{M}+\mathrm{H}]^{+}\right)$.

\section{Hydrodistillation}

A portion of fresh plant material $(323.7 \mathrm{~g})$, represented by leaves and terminal branches, was subjected to hydrodistillation in a Clevenger-type apparatus for $4 \mathrm{~h}$ using $1200 \mathrm{~mL}$ of distilled water. The obtained oil was collected in a Clevenger trap, dried on anhydrous $\mathrm{Na}_{2} \mathrm{SO}_{4}$, stored in hermetically sealed glass vial with rubber lids, protected from light by aluminum foil and kept at $-20{ }^{\circ} \mathrm{C}$ until analysis. The oil yield, on the fresh-weight basis of the plant material, was $0.046 \%(\mathrm{w} / \mathrm{w})$.

\section{GC-FID and GC/MS Analysis}

Firstly, an Agilent 4890D gas chromatograph equipped with an ionization flame detector (FID) was used. Separation was achieved by using a HP-5 capillary column $(5 \%$ phenylmethylpolysiloxane, $25 \mathrm{~m}, 0.32 \mathrm{~mm}$ i.d.; $0.17 \mu \mathrm{m}$ film thickness; J and W Scientific, Folsom, CA). The temperature program of the oven was as follows: $60{ }^{\circ} \mathrm{C}(5 \mathrm{~min})$ then increased up to $220^{\circ} \mathrm{C}$ with a gradient of $4{ }^{\circ} \mathrm{C} / \mathrm{min}$, finally to $280^{\circ} \mathrm{C}$ at $11^{\circ} \mathrm{C} / \mathrm{min}$ held for $15 \mathrm{~min}$. The temperature of injector and transfer line was $280{ }^{\circ} \mathrm{C}$. The carrier gas used was He with a flow rate of $1.4 \mathrm{~mL} / \mathrm{min}$. The essential oil was diluted in hexane and $1 \mu \mathrm{L}$ of the solution was injected into the GC system with a split ratio of 1:34. The temperature-programmed retention indices were calculated according to the Van den Dool and Kratz formula ${ }^{[79]}$ using a mixture of $C_{8}-C_{30} n$-alkanes (Sigma, Milan, Italy) diluted in hexane. Analysis was run in triplicate and data collected by the HP3398A
GC Chemstation software (Hewlett Packard, Rev. A.01.01). Essential oil component percentages were obtained by using a previously developed method by calculating the FID-response factors for the main chemical classes occurring in the essential oil. ${ }^{[80]}$

Qualitative analysis was performed on an Agilent $6890 \mathrm{~N}$ gas chromatograph equipped with a 5973N mass spectrometer. Separation of volatiles was achieved on a HP-5 MS (5\% phenylmethylpolysiloxane, $30 \mathrm{~m}, 0.25 \mathrm{~mm}$ i.d., $0.1 \mu \mathrm{m}$ film thickness; J \& W Scientific, Folsom) capillary column using the same temperature program reported above. The temperature of injector and detector was set to $280^{\circ} \mathrm{C}$ and He was used as carrier gas with a flow rate of $1 \mathrm{~mL} / \mathrm{min}$. The essential oil was diluted in hexane (1:100) and injected $(2 \mu \mathrm{L})$ into the GC/MS system using a split ratio of 1:50. Mass spectra were acquired using electronimpact (EI) mode (ionization voltage: $70 \mathrm{eV}$ ) in the range $m / z 29-400$. The MSD ChemStation software (Agilent, Version G1701DA D.01.00) and NIST Mass Spectral Search Program for the NIST/EPA/NIH Mass Spectral Library v. $2.0^{[81]}$ were used to analyze data. The peak assignment was achieved by co-injection with authentic standard whenever possible (see Table 1), or by correspondence of the temperatureprogrammed retention indices (Rls) and acquired mass spectra (MS) with respect to those reported in commercial $^{[81-83]}$ and home-made libraries.

\section{Cytotoxicity Assay}

A375 human malignant melanoma cell line and MDAMB 231 human breast adenocarcinoma cell line were maintained in Dulbecco's Modified Eagle's Medium (DMEM). This medium was supplemented with $10 \%$ heat-inactivated fetal bovine serum (HI-FBS), 100 $\mathrm{IU} / \mathrm{mL}$ penicillin, $100 \mu \mathrm{g} / \mathrm{mL}$ streptomycin and $2 \mathrm{~mm}$ L-glutamine. HCT116 human colon carcinoma cell line was maintained in RPMI1640 medium supplemented with $10 \% \mathrm{HI}-\mathrm{FBS}, 100 \mathrm{IU} / \mathrm{mL}$ penicillin, $100 \mu \mathrm{g} / \mathrm{mL}$ streptomycin and $2 \mathrm{~mm}$ L-glutamine. The cultures were maintained in a humidified atmosphere at $37{ }^{\circ} \mathrm{C}$ in presence of $5 \% \mathrm{CO}_{2}$. Cells were subcultured every $3-4$ days. The cytotoxicity was assessed using the MTT (3-(4,5-dimethylthiazol-2-yl)-2,5-diphenyl-2H-tetrazolium bromide) assay. ${ }^{[84]}$ In brief, cells $\left(2 \times 10^{4}\right.$ cells $\left./ \mathrm{mL}\right)$ were seeded on 96-well plates and incubated for $24 \mathrm{~h}$ in a humidified atmosphere of $5 \% \mathrm{CO}_{2}$ at $37{ }^{\circ} \mathrm{C}$. Then, essential oil $(1.56-400 \mu \mathrm{g} / \mathrm{mL})$ and polar compounds $(0.001-100 \mu \mathrm{m})$ were added to the supernatant and the samples were incubated for a further $72 \mathrm{~h}$. At the end of incubation, each well received $10 \mu \mathrm{L}$ of $\mathrm{MTT}$ ( $5 \mathrm{mg} / \mathrm{mL}$ in phosphate-buffered saline, PBS) and the 
plates were incubated for $4 \mathrm{~h}$ at $37{ }^{\circ} \mathrm{C}$. After removal of the supernatant, DMSO was added to solubilize water-insoluble dark blue formazan crystals formed in viable cells and the absorbance was measured at $540 \mathrm{~nm}$ using a Titertek Multiscan microElisa (Labsystems, Fl-Helsinki). The cytotoxicity was expressed as the concentration of compound inhibiting cell growth by $50 \%\left(\mathrm{IC}_{50}\right)$ and was calculated with GraphPad Prism 4 computer program (GraphPad Software, S. Diego, CA, USA). Experiments were conducted in triplicate.

\section{Antioxidant Activity}

Free radical scavenging activity (DPPH) was evaluated on a microplate analytical assay according to the procedures previously described by Srinivasan and co-workers. ${ }^{[85]}$ The stock solution was prepared by dissolving DPPH in methanol and then stored at $-20^{\circ} \mathrm{C}$ until use. The working solution was obtained by mixing stock solution with methanol to obtain an absorbance of 1 unit at $517 \mathrm{~nm}$. Discoloration was measured at $517 \mathrm{~nm}$ after incubation for $30 \mathrm{~min}$ in the dark. The free radical-scavenging activity of each solution was then calculated as percent inhibition according to the following equation:

$\%$ Inhibition $=100 \times\left(A_{\text {blank }}-A_{\text {sample }}\right) / A_{\text {blank }}$

Antioxidant activity of the essential oil and isolated compounds was expressed as $I C_{50}$, defined as the concentration of the test material required to cause a $50 \%$ decrease in initial DPPH concentration. Trolox was used as reference. Results were expressed in $\mu \mathrm{m}$ Trolox equivalents (TE)/g of essential oil.

The $\mathrm{ABTS}^{+}$assay was performed following the procedure described previously, ${ }^{[86]}$ applied to a 96-well microplate assay. ${ }^{[87]}$ The ABTS ${ }^{+}$stock solution was prepared by mixing the two solutions of $\mathrm{ABTS}^{+}(7.4 \mathrm{~mm})$ and potassium persulfate $(2.6 \mathrm{~mm})$ in equal quantities and allowing them to react for $12 \mathrm{~h}$ at room temperature and in the dark. The working solution was then obtained by mixing $\mathrm{ABTS}^{+}$stock solution with methanol (or ethanol) to obtain a final solution with absorbance about 1 unit at $734 \mathrm{~nm}$. Absorbance values were measured with a Varian Cary 1 spectrophotometer and Trolox was used as reference compound. Results were expressed in $\mu \mathrm{m}$ Trolox equivalents (TE)/g of product or essential oil. The capacity of free radical scavenging $\left(\mathrm{IC}_{50}\right)$ was determined using an analogous equation to those previously used in the DPPH method. All data of antioxidant activity were expressed as means \pm standard deviations (SD) of triplicate measurements. The confidence limits were set at $P<0.05$.
SD did not exceed $5 \%$ for the majority of the values obtained.

The reducing capacity power (FRAP) assay was carried out according to Firuzi and co-workers, ${ }^{[88]}$ with minor modifications. The stock solutions included $300 \mathrm{~mm}$ acetate buffer, pH 3.6, $10 \mathrm{~mm}$ TPTZ (2,4,6tripyridyl-S-triazine) solution in $40 \mathrm{~mm} \mathrm{HCl}$, and $20 \mathrm{~mm}$ $\mathrm{FeCl}_{3} \cdot 6 \mathrm{H}_{2} \mathrm{O}$ solution. The fresh working solution was prepared by mixing $25 \mathrm{~mL}$ acetate buffer, $2.5 \mathrm{~mL}$ TPTZ solution, and $2.5 \mathrm{~mL} \mathrm{FeCl} \cdot 6 \mathrm{H}_{2} \mathrm{O}$ solution and then warmed at $37{ }^{\circ} \mathrm{C}$ before use. Aliquots of diluted essential oil and isolated compounds in methanol allowed to react with $500 \mu \mathrm{L}$ of the FRAP solution for $30 \mathrm{~min}$ in the dark. Samples were centrifuged at 11 '500 $\mathrm{g}$ and the withdrawn aliquots of solutions containing the colored product (ferrous tripyridyltriazine complex; $280 \mu \mathrm{L}$ ) were read in 96-well microplates at $593 \mathrm{~nm}$. The standard curve was linear between 25 and $800 \mu \mathrm{m}$ Trolox used as positive control. Results were expressed in $\mu \mathrm{m} \mathrm{TE} / \mathrm{g}$ of product or essential oil. Additional dilution was applied when the measured FRAP value resulted over the linear range of the standard curve.

\section{Supplementary Material}

Supporting information for this article is available on the WWW under https://doi.org/10.1002/cbdv.201800148.

\section{Acknowledgements}

Authors would like to thank University of Camerino (FAR 2014/15, Fondo di Ateneo per la Ricerca, FPI000044) for financial support.

\section{Author Contribution Statement}

A. Venditti conceived and designed the experiments, performed the chromatographic separation of the ethanol fraction, analyzed the data, performed the structure elucidation of isolated compounds, supervise the hydrodistillation of the essential oil and wrote the article. F. Maggi analyzed the essential oil and conceived the experiments. L. Quassinti and M. Bramucci performed cytotoxic assays. G. Lupidi carried out the antioxidant assays. L. Ornano collected the plant materials, obtained the ethanolic extracts and performed the hydrodistillation. M. Ballero and C. Sanna performed the botanical identification of plant materials. M. Bruno and S. Rosselli contributed to the structure identification of isolated compounds. A. Bianco supervised the experiments and contributed to organic solvents, reagents, materials, analysis tools, analyzed the 
data and checked the final version of the article. All the co-authors contributed to the writing of the article on the basis of their competence.

\section{Conflict of Interest}

All the authors declare no conflict of interest.

\section{References}

[1] A. Farjon, 'A monograph of Cupressaceae and Sciadopitys', Royal Botanic Gardens, Kew, 2005.

[2] A. Farjon, 'A Handbook of the World's Conifers', EJ Brill, Leiden/Boston, 2010.

[3] R. P. Adams, 'The Junipers of the World: The Genus Juniperus', 3rd edn. Trafford Publishing Co., Victoria, BC, 2011.

[4] R. P. Adams, A. E. Schwarzbach, 'Taxonomy of the Multiseeded, Entire Leaf Taxa of Juniperus Section Sabina: Sequences Analysis of nrDNA and Four cpDNA Regions', Phytologia 2012, 94, 350 - 368.

[5] M. Mazur, P. Minissale, S. Sciandrello, A. Boratyński, 'Morphological and Ecological Comparison of Populations of Juniperus turbinata Guss. and J. phoenicea L. from the Mediterranean Region', Plant Biosyst. 2016, 150, 313 - 322.

[6] P. P. Ferrer-Gallego, R. Nazzaro, I. Ferrando-Pardo, E. Laguna, 'Typification of the Mediterranean Endemic Conifer Juniperus turbinata (Cupressaceae)', Phytotaxa 2017, 302, $165-173$.

[7] R. Adams, A. Boratynski, M. Arista, A. E. Schwarzbach, H. Leschner, Z. Liber, P. Minissale, T. Mataraci, A. Manolis, 'Analysis of Juniperus phoenicea from Throughout Its Range in the Mediterranean Using DNA Sequence Data from nrDNA and petN-psbM: The Case for the Recognition of J. turbinata Guss.', Phytologia 2015, 95, 202 - 209.

[8] S. Pignatti, 'Flora d'Italia', Edagricole, Bologna, 1982.

[9] J. Bellakhder, 'La Pharmacopée Marocaine traditionnelle', Ibis Press, Paris, 1997.

[10] M. Amer, M. Wasif, A. Abo-Aytta, 'Chemical and Biological Evaluation of Juniperus phoenicea as a Hypoglycaemic Agent', J. Agric. Res. 1994, 21, 1077 - 1091.

[11] H. Allali, H. Benmehdi, M. A. Dib, B. Tabti, S. Ghalem, N. Benanadji, 'Phytotherapy of Diabetes in West Algeria', Asian J. Chem. 2008, 20, 2701 - 2710.

[12] V. Stassi, E. Verykokidou, A. Loukis, C. Harvala, S. Philianos, 'The Antimicrobial Activity of the Essential Oils of Four Juniperus Species Growing Wild in Greece', Flavour Fragrance J. 1996, 11, $71-74$.

[13] A. Angioni, A. Barra, M. T. Russo, V. Coroneo, S. Dessi, P. Cabras, 'Chemical Composition of the Essential Oils of Juniperus from Ripe and Unripe Berries and Leaves and Their Antimicrobial Activity', J. Agric. Food Chem. 2003, 51, 3073 - 3078.

[14] E. Derwich, Z. Benziane, A. Boukir, 'Chemical Composition of Leaf Essential Oil of Juniperus phoenicea and Evaluation of its Antibacterial Activity', Int. J. Agric. Biol. 2010, 12, 199 - 204.

[15] E. Lamerzarawska, 'Biflavonoids in Juniperus L. sp. (Cupressaceae)', Pol. J. Pharmacol. Pharm. 1975, 27, $81-87$.

[16] J. de Pascual Teresa, A. F. Barrero, L. Muriel, A. San Feliciano, M. Grande, 'New Natural Diterpenes Acid from Juniperus communis', Phytochemistry 1980, 19, 1153 - 1156.
[17] G. Comte, D. P. Allais, A. J. Chulia, J. Vercauteren, N. Pinaud, 'Three Phenylpropanoids from Juniperus phoenicea', Phytochemistry 1997, 44, 1169 - 1173.

[18] V. Stassi, E. Verykokidou, A. Loukis, C. Harvala, 'Polyphenolic Compounds from the Leaves of Juniperus oxycedrus L. subsp. macrocarpa (Sm.)' Ball. Pharm. Acta Helv. 1998, 72, $311-312$.

[19] A. F. Barrero, J. F. Quilez del Moral, M. M. Herrador, M. Akssira, A. Bennamara, S. Akkad, M. Aitigri, 'Oxygenated Diterpenes and Other Constituents from Moroccan Juniperus phoenicea and Juniperus thurifera var. africana', Phytochemistry 2004, 65, 2507 - 2515.

[20] M. Mazur, K. Boratynska, K. Marcysiak, D. Gomez, D. Tomaszewski, J. Didukh, A. Boratynski, 'Morphological Variability of Juniperus phoenicea [Cupressaceae] from Three Distant Localities on Iberian Peninsula', Acta Soc. Bot. Pol. Pol. Tow. Bot. 2003, 72, $71-78$.

[21] R. P. Adams, N. Pandey, S. Rezzi, J. Casanova, 'Geographic Variation in the Random Amplified Polymorphic DNAs (RAPDs) of Juniperus phoenicea, J.p. var. canariensis, J.p. subsp. eu-mediterranea, and J.p. var. turbinata', Biochem. Syst. Ecol. 2002, 30, 223 - 229.

[22] M. Meloni, D. Perini, R. Filigheddu, G. Binelli, 'Genetic Variation in Five Mediterranean Populations of Juniperus phoenicea as Revealed by Inter-Simple Sequence Repeat (ISSR) Markers', Ann. Bot. 2006, 97, 299 - 304.

[23] A. Boratynski, A. Lewandowski, K. Boratynska, J. M. Montserrat, A. Romo, 'High Level of Genetic Differentiation of Juniperus phoenicea (Cupressaceae) in the Mediterranean Region: Geographic Implications', Plant Syst. Evol. 2009, 277, 163 - 172.

[24] M. Mazur, K. Klajbor, M. Kielich, M. Sowinska, A. M. Romo Diez, J. M. M. Marti, A. Boratynski, 'Intra-specific Differentiation of Juniperus phoenicea in the Western Mediterranean Region Revealed in Morphological Multivariate Analysis', Dendrobiology 2010, 63, 21 - 31.

[25] C. Cavaleiro, S. Rezzi, L. Salgueiro, A. Bighelli, J. Casanova, A. P. da Cunha, 'Infraspecific Chemical Variability of the Leaf Essential Oil of Juniperus phoenicea var. turbinata from Portugal', Biochem. Syst. Ecol. 2001, 29, $1175-1183$.

[26] A. Ait-Ouazzou, S. Lorán, A. Arakrak, A. Laglaoui, C. Rota, A. Herrera, R. Pagán, P. Conchello, 'Evaluation of the Chemical Composition and Antimicrobial Activity of Mentha pulegium, Juniperus phoenicea, and Cyperus longus Essential Oils from Morocco', Food Res. Int. 2012, 45, 313 - 319.

[27] K. Mazari, N. Bendimerad, C. Bekhechi, X. Fernandez, 'Chemical Composition and Antimicrobial Activity of Essential Oils Isolated from Algerian Juniperus phoenicea L. and Cupressus sempervirens L.', J. Med. Plants Res. 2010, 4, 959 - 964.

[28] H. Medini, A. Elaissi, F. Farhat, M. L. Khouja, R. Chemli, F. Harzallah-Skhiri, 'Seasonal and Geographical Influences on the Chemical Composition of Juniperus phoenicea L. Essential Oil Leaves from the Northern Tunisia', Chem. Biodiversity 2009, 6, $1378-1387$.

[29] N. Mansouri, B. Satrani, M. Ghanmi, L. El Ghadraoui, A. Boukir, A. Aafi, 'Effet de la Provenance sur le rendement, la composition chimique et l'activité antimicrobienne des huiles essentielles des rameaux de Juniperus phoenicea $\mathrm{L}$. du Maroc', Acta Bot. Gall. 2011, 158, 215 - 224. 
[30] C. Tabacik, C. Poisson, 'Diterpenes de Juniperus phoenicea: Constituants Mineurs', Phytochemistry 1971, 10, 1639 - 1645.

[31] A. M. Dawidar, S. T. Ezmirly, M. Abdel-Mogib, 'Sesquiterpenes and Diterpenes from Juniperus phoenicea L.', Pharmazie 1991, 46, 472 - 473.

[32] Y. Champavier, G. Comte, J. Vercauteren, D. P. Allais, A. J. Chulia, 'Norterpenoid and Sesquiterpenoid Glucosides from Juniperus phynicea and Galega officinalis', Phytochemistry 1999, 50, $1219-1223$.

[33] M. Aboul-Ela, N. El-Shaer, T. A. El-Azim, 'Chemical Constituents and Antihepatotoxic Effect of Juniperus Phoenicea Berries - Part II', Nat. Prod. Sci. 2005, 11, 240 - 247.

[34] G. Comte, D. P. Allais, A. J. Chulia, J. Vercauteren, C. Delage, 'Two Furanone Glucoside Derivatives from Juniperus phoenicea', Phytochemistry 1996, 41, 1329 - 1332.

[35] G. Comte, A. J. Chulia, J. Vercauteren, D. P. Allais, 'Phenylpropane Glycosides from Juniperus phoenicea', Planta Med. 1996, 62, $88-89$.

[36] D. A. Caibnes, O. Ekundayo, D. G. I. Kingston, 'Plant Anticancer Agents. X. Lignans From Juniperus phoenicea', J. Nat. Prod. 1980, 43, 495 - 497.

[37] A. San Feliciano, J. M. Miguel Del Corral, M. Gordaliza, M. A. Salinero, B. Del Rey, 'Acid Constituents of Juniperus phoenicea subsp. turbinata Leaves', Fitoterapia 1993, 64, $185-186$.

[38] G. Schmeda-Hirschmann, L. Astudillo, B. Sepúlveda, J. A. Rodríguez, C. Theoduloz, T. Yáñez, J. A. Palenzuela, 'Gastroprotective Effect and Cytotoxicity of Natural and Semisynthetic Labdane Diterpenes from Araucaria araucana Resin', Z. Naturforsch. C 2005, 60, $511-522$.

[39] J. A. Garbarino, M. L. Oyarzun, V. Gambaro, 'Labdane Diterpenes from Araucaria araucana', J. Nat. Prod. 1987, 50, $935-936$.

[40] A. Venditti, C. Frezza, F. Maggi, G. Lupidi, M. Bramucci, L. Quassinti, C. Giuliani, K. Cianfaglione, F. Papa, M. Serafini, A. Bianco, 'Phytochemistry, Micromorphology and Bioactivities of Ajuga chamaepitys (L.) Schreb. (Lamiaceae, Ajugoideae): Two New Harpagide Derivatives and an Unusual Iridoid Glycosides Pattern', Fitoterapia 2016, 113, 35 - 43.

[41] A. Venditti, S. E. Ukwueze, 'A Possible Glycosidic Benzophenone with Full Substitution on B-ring from Psidium guajava Leaves', Nat. Prod. Res. 2017, 31, 739 - 741.

[42] A. Venditti, C. Frezza, I. Serafini, A. Ciccòla, F. Sciubba, M. Serafini, A. Bianco, 'Iridoids of Chemotaxonomy Relevance, a New Antirrhinoside Ester and Other Constituents from Kickxia spuria subsp. integrifolia (BRot.) R.Fern.', Chem. Biodiversity 2018, 15, e1700473.

[43] C. Sanna, M. Scognamiglio, A. Fiorentino, A. Corona, V. Graziani, A. Caredda, P. Cortis, M. Montisci, E. R. Ceresola, F. Canducci, F. Poli, E. Tramontano, F. Esposito, 'Prenylated Phloroglucinols from Hypericum scruglii, an Endemic Species of Sardinia (Italy), as New Dual HIV-1 Inhibitors Effective on HIV-1 Replication', PLOS ONE 2018, 13, e0195168.

[44] F. Esposito, C. Sanna, C. Del Vecchio, V. Cannas, A. Venditti, A. Corona, A. Bianco, A. M. Serrilli, L. Guarcini, C. Parolin, M. Ballero, E. Tramontano, 'Hypericum hircinum L. Components as New Single-molecule Inhibitors of both HIV-1 Reverse Transcriptase-associated DNA Polymerase and Ribonuclease H Activities', Pathog. Dis. 2013, 68, $116-124$
[45] A. Bianco, A. M. Serrilli, A. Venditti, V. Petitto, M. Serafini, 'Endemic Plants of Italy and Their Peculiar Molecular Pattern', Stud. Nat. Prod. Chem. 2016, 50, 215 - 247.

[46] A. Venditti, A. M. Serrilli, S. Vittori, F. Papa, F. Maggi, M. Di Cecco, G. Ciaschetti, M. Bruno, S. Rosselli, A. Bianco, 'Secondary Metabolites from Pinus mugo TurRa subsp. mugo Growing in the Majella National Park (Central Apennines, Italy)', Chem. Biodiversity 2013, 10, 2091 - 2100.

[47] A. Venditti, A. M. Serrilli, A. Bianco, 'Iridoids from Bellardia trixago (L.) All.', Nat. Prod. Res. 2013, 27, 1413 - 1416.

[48] A. Venditti, L. Guarcini, M. Ballero, A. Bianco, 'Iridoid Glucosides from Pentas lanceolata (Forssk.) Deflers Growing on the Island of Sardinia', Plant Syst. Evol. 2015, 301, 685 - 690.

[49] A. Venditti, M. Ballero, M. Serafini, A. Bianco, 'Polar Compounds from Parentucellia viscosa (L.) Caruel from Sardinia', Nat. Prod. Res. 2015, 29, $602-606$.

[50] A. Venditti, C. Lattanzi, L. Ornano, F. Maggi, C. Sanna, M. Ballero, A. Alvino, M. Serafini, A. Bianco, 'A New Glucosidic Phthalide from Helichrysum microphyllum subsp. tyrrhenicum from La Maddalena Island (Sardinia, Italy)', Nat. Prod. Res. 2016, 30, 789 - 795.

[51] A. Venditti, C. Sanna, L. M. Lorenzetti, M. Ballero, A. Bianco, 'New Coumarinyl Ethers in Daphne oleoides Schreb. Collected from Sardinia Island', Chem. Biodiversity 2017, 14, e1700072.

[52] K. W. Woo, S. U. Choi, J. C. Park, K. R. Lee, 'A New Lignan Glycoside from Juniperus rigida', Arch. Pharm. Res. 2011, 34, $2043-2049$.

[53] S. I. Alquasoumi, A. I. Farraj, M. S. Abdel-Kader, 'Study of the Hepatoprotective Effect of Juniperus phoenicea Constituents', Pak. J. Pharm. Sci. 2013, 26, 999 - 1008.

[54] W. Fatma, H. M. Taufeeq, W. A. Shaida, W. Rahman, 'Biflavanoids from Juniperus macropoda Boiss and Juniperus phoenicea Linn. (Cupressaceae)', Indian J. Chem. B Org. 1979, 17, 193 - 194.

[55] G. T. Maatooq, S. H. El-Sharkawy, M. S. Afifi, J. P. N. Rosazza, 'Flavonoids from two Cupressaceae Plants', Nat. Prod. Sci. 1998, 4, $9-14$.

[56] L. Tavares, G. J. McDougall, S. Fortalezas, D. Stewart, R. B. Ferreira, C. N. Santos, 'The Neuroprotective Potential of Phenolic-enriched Fractions from four Juniperus Species Found in Portugal', Food Chem. 2012, 135, 562 - 570.

[57] S. B. Hassan, H. Gali-Muhtasib, H. Göransson, R. Larsson, ' $\alpha$-Terpineol: A Potential Anticancer Agent which Acts Through Suppressing NF- $\kappa$ B Signalling', Anticancer Res. 2010, 30, 1911 - 1919.

[58] M. G. B. de Oliveira, R. B. Marques, M. F. de Santana, A. B. D. Santos, F. A. Brito, E. O. Barreto, D. P. De Sousa, F. R. C. Almeida, D. Badauê-Passos Jr, Â. R. Antoniolli, L. J. Quintans-Júnior, ' $\alpha$-Terpineol Reduces Mechanical Hypernociception and Inflammatory Response', Basic Clin. Pharmacol. Toxicol. 2012, 111, $120-125$.

[59] S. Rezzi, C. Cavaleiro, A. Bighelli, L. Salgueiro, A. P. da Cunha, J. Casanova, 'Intraspecific Chemical Variability of the Leaf Essential Oil of Juniperus phoenicea subsp. turbinata from Corsica', Biochem. Syst. Ecol. 2001, 29, 179 - 188.

[60] C. Bekhechi, F. Atik Bekkara, D. Consiglio, A. Bighelli, F. Tomi, 'Chemical Variability of the Essential Oil of Juniperus phoenicea var. turbinata from Algeria', Chem. Biodiversity 2012, 9, $2742-2753$.

[61] M. Ennajar, J. Bouajila, A. Lebrihi, F. Mathieu, M. Abderraba, A. Raies, M. Romdhane, 'Chemical Composition and 
Antimicrobial and Antioxidant Activities of Essential Oils and Various Extracts of Juniperus phoenicea L. (Cupressacees)', Food Microbiol. Safety 2009, 74, 364 - 371.

[62] L. Ornano, A. Venditti, Y. Donno, C. Sanna, M. Ballero, A. Bianco, 'Phytochemical Analysis of Non-volatile Fraction of Artemisia caerulescens subsp. densiflora (Viv.) (Asteraceae), an Endemic Species of La Maddalena Archipelago (Sardinia - Italy)', Nat. Prod. Res. 2013, 30, 920 - 925.

[63] L. Ornano, A. Venditti, C. Sanna, M. Ballero, F. Maggi, G. Lupidi, M. Bramucci, L. Quassinti, A. Bianco, 'Chemical Composition and Biological Activity of the Essential Oil from Helichrysum microphyllum Cambess. ssp. tyrrhenicum Bacch., Brullo e Giusso growing in La Maddalena Archipelago, Sardinia', J. Oleo Sci. 2015, 64, 19 - 26.

[64] L. Ornano, A. Venditti, M. Ballero, C. Sanna, L. Quassinti, L. Bramucci, G. Lupidi, F. Papa, S. Vittori, F. Maggi, A. Bianco, 'Chemopreventive and Antioxidant Activity of the Chamazulene-Rich Essential Oil Obtained from Artemisia arborescens L. Growing on the Isle of La Maddalena, Sardinia, Italy', Chem. Biodiversity 2013, 10, 1464 - 1474.

[65] A. Garozzo, R. Timpanaro, A. Stivala, G. Bisignano, A. Castro, 'Activity of Melaleuca alternifolia (tea tree) oil on Influenza virus A/PR/8: Study on the Mechanism of Action', Antiviral Res. 2011, 89, 83 - 88.

[66] S. De Marino, F. Cattaneo, C. Festa, F. Zollo, A. Iaccio, R. Ammendola, F. Incollingo, M. Iorizzi, 'Imbricatolic Acid from Juniperus communis L. Prevents Cell Cycle Progression in CaLu-6 Cells', Planta Med. 2011, 77, 1822 - 1828.

[67] M. W. Pertino, C. Lopez, C. Theoduloz, G. Schmeda-Hirschmann, '1,2,3-Triazole-Substituted Oleanolic Acid Derivatives: Synthesis and Antiproliferative Activity', Molecules 2013, 18, 7661 - 7674.

[68] H. P. Kim, H. Park, K. H. Son, H. W. Chang, S. S. Kang, 'Biochemical Pharmacology of Biflavonoids: Implications for Antiinflammatory Action', Arch. Pharm. Res. 2008, 31, 265 - 273.

[69] E. Al-Sayed, M. M. Abdel-Daim, 'Protective Role of Cupressuflavone from Cupressus macrocarpa Against Carbon Tetrachloride-induced Hepato- and Nephrotoxicity in Mice', Planta Med. 2014, 80, 1665 - 1671.

[70] G.-H. Xu, I.-J. Ryoo, Y.-H. Kim, S.-J. Choo, I.-D. Yoo, 'Free Radical Scavenging and Antielastase Activities of Flavonoids from the Fruits of Thuja orientalis', Arch. Pharm. Res. 2009, 32, $275-282$.

[71] J. A. Siddiqui, G. Swarnkar, K. Sharan, B. Chakravarti, G. Sharma, P. Rawat, M. Kumar, F. M. Khan, D. Pierroz, R. Maurya, N. Chattopadhyay, '8,8'-Biapigeninyl Stimulates Osteoblast Functions and Inhibits Osteoclast and Adipocyte Functions: Osteoprotective Action of 8,8"-Biapigeninyl in Ovariectomized Mice', Mol. Cell. Endocrinol. 2010, 323, 256 - 267.

[72] C. Theoduloz, C. Delporte, G. Valenzuela-Barra, X. Silva, S. Cádiz, F. Bustamante, M. W. Pertino, G. Schmeda-Hirschmann, 'Topical Anti-inflammatory Activity of New Hybrid Molecules of Terpenes and Synthetic Drugs', Molecules 2015, 20, 11219 - 11235.

[73] M. F. Khan, C. Sourabh Azad, A. Kumar, M. Saini, A. Kumar Narula, S. Jain, 'Novel Imbricatolic Acid Derivatives as Protein Tyrosine Phosphatase-1B Inhibitors: Design, Synthesis, Biological Evaluation and Molecular Docking', Bioorg. Med. Chem. Lett. 2016, 26, 1988 - 1992.

[74] A. Venditti, C. Frezza, C. Campanelli, S. Foddai, A. Bianco, M. Serafini, 'Phytochemical Analysis of the Ethanolic
Extract of Agathis robusta (C. Moore ex F. Muell.) FM Bailey', Nat. Prod. Res. 2017, 31, 1604 - 1611.

[75] J. R. Hanrahan, M. Chebib, N. L. M. Davucheron, B. J. Hall, G. A. R. Johnston, 'Semisynthetic Preparation of Amentoflavone: A Negative Modulator at GABA(A) Receptors', Bioorg. Med. Chem. Lett. 2003, 13, 2281 - 2284.

[76] C. Demetzos, A. Kolocouris, T. Anastasaki, 'A Simple and Rapid Method for the Differentiation of C-13 Manoyl Oxide Epimers in Biologically Important Samples Using GC/MS Analysis Supported with NMR Spectroscopy and Computational Chemistry Results', Bioorg. Med. Chem. Lett. 2002, $12,3605-3609$.

[77] N. Muto, T. Tomokuni, M. Haramoto, H. Tatemoto, T. Nakanishi, Y. Inatomi, H. Murata, A. Inada, 'Isolation of Apoptosisand Differentiation-inducing Substances Toward Human Promyelocytic Leukemia HL-60 Cells from Leaves of Juniperus taxifolia', Biosci. Biotechnol. Biochem. 2008, 72, 477 - 484.

[78] S. W.-C. Su, J.-M. Fang, Y.-S. Cheng, 'Labdanes from Cryptomeria japonica', Phytochemistry 1994, 37, 1109 - 1114.

[79] H. van den Dool, P. D. Kratz, 'A Generalization of the Retention Index System Including Linear Temperature Programmed Gas-Liquid Partition Chromatography', J. Chromatogr. A 1963, 11, $463-471$.

[80] F. Maggi, F. Papa, G. Cristalli, G. Sagratini, S. Vittori, C. Giuliani, 'Histochemical Localization of Secretion and Composition of the Essential Oil in Melittis melissophyllum L. subsp. melissophyllum from Central Italy', Flavour Fragrance J. 2010, 25, $63-70$.

[81] NIST 08, National Institute of Standards and Technology, Mass Spectral Library (NIST/EPA/NIH), National Institute of Standards and Technology, Gaithersburg (MD), 2008.

[82] R. P. Adams, 'Identification of Essential Oil Components by Gas Chromatography/Mass Spectrometry', 4th edn. Allured, Carol Stream, IL, 2007.

[83] L. Mondello, 'FFNSC 2, Flavors and Fragrances of Natural and Synthetic Compounds 2', 2nd edn. Mass Spectral Database, Wiley.

[84] L. Quassinti, G. Lupidi, F. Maggi, G. Sagratini, F. Papa, S. Vittori, A. Bianco, M. Bramucci, 'Antioxidant and Antiproliferative Activity of Hypericum hircinum L. subsp. majus (Aiton) N. Robson Essential Oil', Nat. Prod. Res. 2013, 27, 865 - 868.

[85] R. Srinivasan, M. J. N. Chandrasekar, M. J. Nanjan, B. Suresh, 'Antioxidant Activity of Caesalpinia digyna Root', J. Ethnopharmacol. 2007, 113, 284 - 291.

[86] R. Re, N. Pellegrini, A. Proteggente, A. Pannala, M. Yang, C. Rice-Evans, 'Antioxidant Activity Applying an Improved ABTS Radical Cation Decolorization Assay', Free Radical Biol. Med. 1999, 26, 1231 - 1237.

[87] J. R. Esparza Rivera, M. B. Stone, C. Stushnoff, E. PilonSmits, P. A. Kendall, 'Effects of Ascorbic Acid Applied by Two Hydrocooling Methods on Physical and Chemical Properties of Green Leaf Lettuce Stored at $5^{\circ} \mathrm{C}^{\prime}$, J. Food Sci. 2006, 71, S270 - S276.

[88] O. Firuzi, A. Lacanna, R. Petrucci, G. Marrosu, L. Saso, 'Evaluation of the Antioxidant Activity of Flavonoids by 'Ferric Reducing Antioxidant Power' Assay and Cyclic Voltammetry', Biochim. Biophys. Acta 2005, 1721, $174-184$.

Received April 9, 2018 Accepted May 18, 2018 